UNIVERSIDADE DE SÃO PAULO

FACULDADE DE FILOSOFIA, CIÊNCIAS E LETRAS DE RIBEIRÃO PRETO PROGRAMA DE PÓS-GRADUAÇÃo EM EDUCAÇÃO

\title{
ANÁLISE RETÓRICA DA NARRATIVA MEMORIALÍSTICA DE PASCHOAL LEMME
}

Roberta Aline Sbrana 


\section{ANÁLISE RETÓRICA DA NARRATIVA}

\section{MEMORIALÍSTICA DE PASCHOAL LEMME}

Dissertação apresentada ao Programa de PósGraduação em Educação da Faculdade de Filosofia, Ciências e Letras de Ribeirão Preto da Universidade de São Paulo, para obtenção do título de Mestre em Ciências: Educação. "VERSÃO CORRIGIDA"

Linha de Pesquisa: Fundamentos Filosóficos, Científicos e Culturais da Educação.

Orientador: Prof. Dr. Marcus Vinicius da Cunha 
AUTORIZO A REPRODUÇÃO E DIVULGAÇÃO TOTAL E PARCIAL DESTE

TRABALHO, POR QUALQUER MEIO CONVENCIONAL OU ELETRÔNICO, PARA FINS DE ESTUDO E PESQUISA, DESDE QUE CITADA A FONTE.

FICHA CATALOGRÁFICA

SBRANA, Roberta Aline.

Análise Retórica da Narrativa Memorialística de Paschoal Lemme / Roberta Aline Sbrana; orientador Marcus Vinicius da Cunha. Ribeirão Preto, 2015.

Dissertação apresentada à Faculdade de Filosofia, Ciências e Letras de Ribeirão Preto / USP - Programa de Pós-Graduação em Educação.

1. Memória. 2. Análise Retórica. 3. Educação brasileira. 
Dedico este trabalho ao meu pai, minha mãe e minha irmã, por estarem ao meu lado durante todo o processo de constituição desta pesquisa. 


\section{AGRADECIMENTOS}

Agradeço à Fundação de Amparo à Pesquisa do Estado de São Paulo (FAPESP) por ter me concedido o apoio financeiro que permitiu a concretização deste trabalho.

Agradeço ao professor Marcus Vinicius da Cunha, pela copiosa orientação, apoio, dedicação e conhecimento a mim conferidos no decorrer desses dois anos de desenvolvimento da pesquisa, os quais foram basilares para a efetivação do presente trabalho.

Agradeço ao Grupo de Pesquisa Retórica e Argumentação na Pedagogia (USP/ CNPq), que com suas discussões e produções me permitiram refletir e avançar na constituição desse trabalho.

Agradeço a todos os docentes do Programa de Pós-Graduação em Educação, da Faculdade de Filosofia, Ciências e Letras da Universidade de São Paulo, que contribuíram significativamente para minha formação acadêmica e profissional, em especial aos professores, Elmir de Almeida e Sérgio César da Fonseca.

Agradeço aos professores Tarso Bonilha Mazzotti e Sérgio Adas pela participação na banca de defesa da dissertação, bem como pelas valiosas contribuições oferecidas.

Agradeço às amigas conquistadas no Programa de Pós-graduação em Educação pelas angústias e conquistas compartilhadas.

Agradeço em especial à Tatiane Silva, pela amizade, apoio e paciência incondicionais dedicados a todos os momentos de dúvida, angústia e alegrias nesses dois anos de elaboração deste trabalho.

Agradeço à minha família, por toda amizade e apoio disponibilizados em todos os momentos em que estiveram ao meu lado no desenvolvimento deste trabalho.

Agradeço a Deus, por ter me concedido luz e sabedoria nessa caminhada, me permitindo concluir mais uma etapa da minha vida profissional e acadêmica.

Agradeço enfim, a todos que direta ou indiretamente contribuíram para que esse trabalho fosse concretizado. 


\section{RESUMO}

SBRANA, Roberta Aline. Análise Retórica da Narrativa memorialística de Paschoal Lemme. Dissertação. Faculdade de Filosofia, Ciências e Letras de Ribeirão Preto, Programa de Pós-Graduação em Educação, Universidade de São Paulo, Ribeirão Preto, 2015 .

O presente trabalho investiga o discurso memorialístico de Paschoal Lemme (19041977), educador que atuou no Brasil entre as décadas de 1920 e 1960 no âmbito do movimento denominado Escola Nova. As fontes primárias são os seus livros de memórias publicados pela Editora Cortez/INEP na década de 1980. Estudadas em investigações anteriores, tais fontes são retomadas neste trabalho para serem analisadas por intermédio da análise retórica, metodologia fundamentada em Perelman e Olbrechts-Tyteca. O objetivo é identificar os argumentos centrais e as estratégias argumentativas utilizadas pelo mencionado autor na defesa de sua tese, situando seu intuito persuasivo no contexto de publicação de suas obras, e assim apresentar a análise retórica como alternativa válida para o exame de discursos memorialísticos. O primeiro capítulo discorre sobre a utilização de autobiografias em trabalhos de pesquisa e as situa como objeto de estudo da análise retórica. O segundo capítulo expõe a autobiografia de Paschoal Lemme e contextualiza os fatos narrados visando compreender a imagem por ele criada na exposição de sua vida e atuações. O terceiro capítulo analisa o discurso do autor examinado, focalizando seus argumentos centrais na defesa de suas concepções políticas frente à educação. O quarto capítulo apresenta a análise retórica das memórias do mencionado autor, destacando as estratégias argumentativas presentes em seu discurso, o qual exibe caracteres típicos da geração de intelectuais que atuou entre os anos de 1920 e 1940 no Brasil. A conclusão defende que a imagem messiânica construída por Paschoal Lemme em suas memórias atua como estratégia argumentativa em defesa de sua tese. Nas considerações finais, o trabalho apresenta uma discussão sobre o auditório visado pelo autor ao publicar suas obras na década de 1980, momento marcada pelo debate em torno de diversas concepções educacionais.

\section{Palavras-chave: Memória; Análise Retórica; Educação brasileira.}




\begin{abstract}
Sbrana, Roberta Aline. Rhetoric analysis of narrative memoirs of Paschoal Lemme. Dissertation. Faculty of Philosophy, Sciences and Letters of Ribeirão Preto, the Post Graduating Program in Education, University of São Paulo, Ribeirão Preto, 2015.

This study investigates the memorialist speech of Paschoal Lemme (1904-1977), educator who served in Brazil from the 1920s and 1960s under the movement called New School. The primary sources are his memories published by Editora Cortez / INEP in the 1980s, that was studied in previous investigations and now are analyzed work by means of rhetoric analysis methodology based on Perelman and Olbrechts-Tyteca. The goal is to identify the central arguments and argumentative strategies used by the author in defense of his thesis, placing your persuasive discourse in the context of the publication of his works, and so introduce the rhetorical analysis method as a valid alternative for examining memorialist speeches. The first chapter discusses the use of autobiographies in historical researches placing them as object of rhetoric analysis. The second chapter presents the autobiography of Paschoal Lemme and contextualizes the facts narrated in order to understand the image of his life and actions created by him. The third chapter analyzes the discourse of the author focusing on their core arguments in defense of his political conceptions in education. The fourth chapter presents the rhetoric analysis of the author memories, highlighting the argumentative strategies present in his speech, which displays typical of the generation of intellectuals who served between the years 1920 and 1940 in Brazil. The conclusion argues that the messianic image built by Paschoal Lemme acts as argumentative strategy in defense of his thesis. In the conclusion, the paper presents a discussion of the audience targeted by the author in the 1980s, moment marked by intense debate among several educational concepts.
\end{abstract}

Keywords: Memory; Rhetoric Analysis; Brazilian education. 
I - NARRATIVA MEMORIALÍSTICA E ANÁLISE RETÓRICA.

A relevância da narrativa memorialística....................................................13

Controvérsias acerca da narrativa memorialística....................................19

A análise retórica como alternativa metodológica......................................24

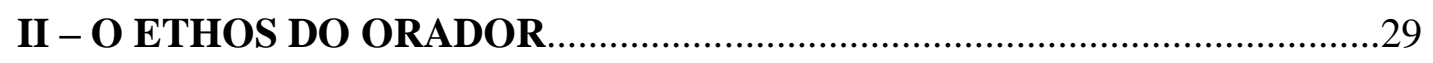

Os primeiros anos de uma trajetória missionária.......................................29

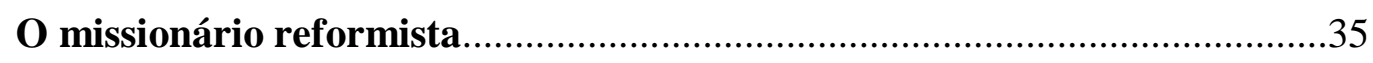

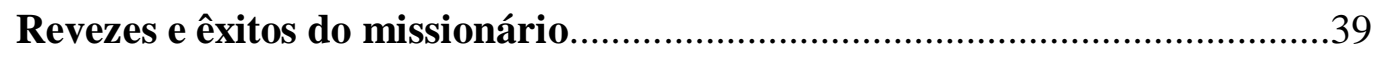

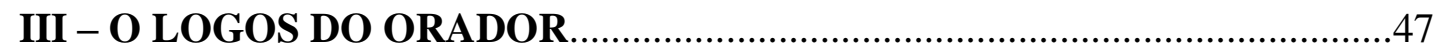

Convergências e divergências do missionário...........................................47

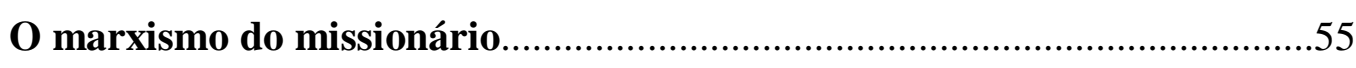

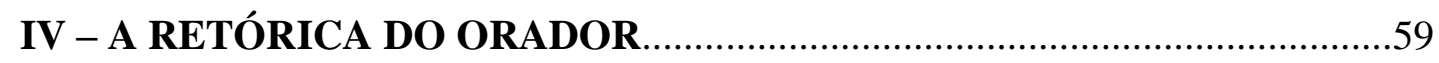

A cena teatral, o herói e as paixões da audiência.......................................59

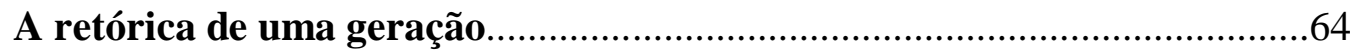

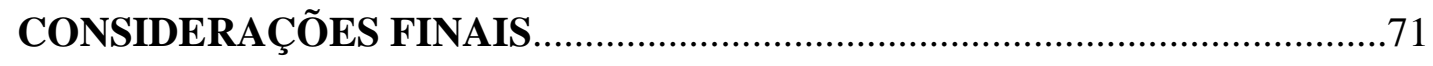

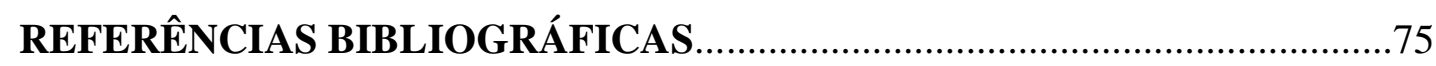




\section{INTRODUÇÃO}

Ao cursar a licenciatura em Pedagogia na Faculdade de Filosofia, Ciências e Letras de Ribeirão Preto da Universidade de São Paulo entre os anos de 2009 e 2012, tive a oportunidade de desenvolver dois projetos de pesquisa sobre Paschoal Lemme, sob a orientação do Prof. Dr. Marcus Vinicius da Cunha, ambos contemplados com bolsa de Iniciação Científica (PIBIC/USP/CNPq) e vinculados ao Grupo de Pesquisa Retórica e Argumentação na Pedagogia (USP/CNPq). ${ }^{1}$

Os dois projetos foram motivados pela escassa quantidade de trabalhos existentes sobre Paschoal Lemme, embora ele tenha sido um educador muito atuante no cenário brasileiro durante várias décadas. Mesmo exercendo inúmeros cargos e funções junto aos líderes do movimento escolanovista - alimentando, segundo as suas próprias palavras, forte amizade por eles -, Lemme foi relegado a plano secundário na História da Educação, permanecendo durante muito tempo praticamente desconhecido nos meios científicos e acadêmicos, em parte devido ao fato de defender ideias alicerçadas no marxismo. Estudá-lo significa contribuir para preencher uma lacuna na historiografia educacional, abrindo caminho para outros pesquisadores investigarem novas questões relativas àquele importante período da educação brasileira.

As únicas pesquisadoras que adotaram Lemme como tema específico de estudo foram Zaia Brandão e Eloá Soares Dutra Kastelic. Brandão publicou sua tese de doutorado no formato de livro com o título A intelligentsia educacional (BRANDÃO, 1999), da qual resultaram dois capítulos em coletâneas, "Paschoal Lemme, marxista e pioneiro da educação nova" (BRANDÃO, 2002b) e "O sentido de uma trajetória: Paschoal Lemme, do Manifesto dos Pioneiros (1932) ao Manifesto dos Inspetores (1934)" (BRANDÃO, 2003). Mais tarde, Kastelic publicou o livro intitulado $O$ percurso de Paschoal Lemme: defesa da escola pública, gratuita e estatal (KASTELIC, 2014).

A primeira pesquisa que realizei, intitulada "Paschoal Lemme e a Escola Nova no Brasil", buscou compreender a posição ocupada por esse autor no âmbito do movimento escolanovista desenvolvido no Brasil entre os anos de 1920 e a década de 1960. Nesse trabalho foram analisados os três primeiros volumes da obra Memórias, de autoria de Lemme, publicados pela Editora Cortez/INEP (LEMME, 1988a; LEMME,

\footnotetext{
${ }^{1}$ Esse Grupo foi criado em 2002, sendo liderado pelos professores Marcus Vinicius da Cunha e Tarso Bonilha Mazzotti e composto por pesquisadores pertencentes a diversas instituições de ensino superior.
} 
1988b; LEMME, 1988c), os quais apresentam a vida do autor, desde a infância até a fase adulta, enfatizando sua paixão pela educação e sua luta constante por uma nova educação. O objetivo da pesquisa foi situar o autor na história da educação brasileira, a partir do que foi possível elaborar algumas indagações acerca de sua autobiografia.

Tais indagações referiam-se à necessidade de compreender com maior exatidão as concepções filosóficas e políticas de Paschoal Lemme, as quais, segundo o próprio autor, contrariavam significativamente os posicionamentos adotados pelos educadores vinculados ao movimento escolanovista. Sendo assim, a segunda investigação que desenvolvi, denominada "Concepções filosóficas e políticas de Paschoal Lemme”, foi dedicada ao estudo dos volumes 4 e 5 daquela mesma obra, Memórias (LEMME, 2004a; LEMME, 2004b), nos quais se encontram diversos textos do autor, elaborados durante os anos de sua atuação na época da Escola Nova.

A partir desses dois trabalhos de pesquisa, elaborei minha monografia de conclusão de curso, intitulada "A Narrativa Memorialística de Paschoal Lemme", defendida em dezembro de 2012, na qual desenvolvi algumas reflexões de caráter mais geral sobre as memórias do autor. Pude notar que, ao descrever os diversos momentos de sua vida, desde a infância até a fase adulta, Lemme procura mostrar-se como um homem altamente interessado em questões educacionais, o que o teria levado a enfrentar inúmeros obstáculos em sua trajetória pessoal e profissional, mesmo sofrendo preconceitos de toda ordem. Lemme explica as influências políticas que definiram a constituição de seu ideário, o qual sempre foi norteado pelo valor da coisa pública, em benefício da nação e do povo.

Foi com base em tais reflexões que redigi meu projeto de mestrado, contemplando utilizar o mesmo material bibliográfico das investigações anteriores - as memórias de Paschoal Lemme - com o intuito de examinar o discurso do autor por meio da perspectiva teórico-metodológica da análise retórica, tal qual se encontra nas produções do Grupo de Pesquisa Retórica e Argumentação na Pedagogia. A perspectiva mais ampla desse Grupo consiste em alicerçar uma metodologia para o exame de discursos educacionais, com especial atenção para os que foram veiculados no Brasil no período de desenvolvimento do movimento escolanovista. O presente trabalho integra essa iniciativa, procurando incluir as narrativas autobiográficas no rol dos objetos passíveis de serem investigados pela análise retórica.

A partir desse referencial teórico e das pesquisas anteriormente realizadas, dediquei-me a alcançar os seguintes objetivos de pesquisa: examinar o discurso 
memorialístico de Paschoal Lemme, por intermédio do estudo de suas obras autobiográficas, focalizando as suas concepções filosóficas, políticas e educacionais; e identificar os argumentos centrais e as estratégias argumentativas contidas no discurso do autor.

É esperado que o cumprimento dessas metas permita o desenvolvimento de reflexões sobre a relação de Lemme com os leitores de suas memórias, os quais, nos termos da análise retórica, são nomeados respectivamente orador e auditório. Tais reflexões permitirão levantar hipóteses sobre as intenções persuasivas do autor perante os educadores que viviam a conjuntura política e educacional da década de 1980, quando as referidas memórias foram publicadas.

O presente trabalho apresenta os resultados da investigação realizada, levando em conta as contribuições dos membros da comissão avaliadora de meu exame de qualificação, as quais foram de inestimável valor para a continuidade da pesquisa e para a adoção de um novo formato para o texto. Este novo formato almeja expressar o modo como se articularam os meus estudos, cujo ponto de partida foi a fonte primária, a autobiografia de Lemme; em seguida, utilizando fontes secundárias, dediquei-me a compreender o contexto em que Lemme atuou, com o intuito de situar as suas ideias e atuações no quadro político e educacional de seu tempo, e também o modo como ele destaca as suas ideias perante as de seus contemporâneos; por fim, busquei analisar o seu discurso por intermédio da metodologia retórica, fazendo uso, mais uma vez, de obras de referência. Espero que a configuração atual do trabalho reflita com clareza o percurso de minha pesquisa.

Antes de iniciar a análise da fonte primária, será feita, no primeiro capítulo, uma discussão sobre o uso da metodologia retórica como ferramenta de investigação de autobiografias. Serão apresentadas as opiniões de autores que valorizam as narrativas memorialísticas como fontes historiográficas, os problemas identificados na utilização desse tipo de material em pesquisas destinadas a esclarecer o passado e, ainda, as alternativas disponíveis para minimizar tais problemas. Por fim, o capítulo argumentará em favor de incluir a análise retórica dentre as possibilidades metodológicas válidas para o estudo de relatos autobiográficos.

Dando início ao exame da fonte primária, o segundo capítulo fará a exposição da autobiografia de Paschoal Lemme, seguindo a ordem cronológica dos fatos apresentados na obra Memórias. Por intermédio de literatura especializada nos temas abordados, tais fatos serão contextualizados no panorama da vida política e educacional 
da época, buscando manter fidelidade ao que é privilegiado pelo autor da narrativa. $\mathrm{O}$ texto buscará compreender a imagem de Lemme que aflora do relato de sua vida e de sua participação nos acontecimentos mais marcantes do período abrangido.

O capítulo terceiro focalizará o discurso de Lemme, destacando as apreciações feitas por ele acerca dos fatos vividos, dos personagens com quem conviveu na vida pública e das ideias que desenvolveu ao longo de sua trajetória como educador. A análise incidirá, portanto, nas teses apresentados pelo autor quanto aos problemas da educação, focalizando os seus posicionamentos políticos, os quais, segundo ele mesmo, exibiam profunda divergência ante os defendidos e postos em prática por seus pares.

O último capítulo utilizará os referenciais expostos no capítulo inicial para apresentar a retórica de Lemme, valendo-se, para isso, do material investigado nos dois capítulos intermediários. Além de discorrer sobre as estratégias argumentativas do autor examinado, a seção buscará mostrar que as características de seu discurso integram um modo de expressão típico de uma geração em que os intelectuais compartilhavam do ideal de transformar o Brasil. Procuraremos mostrar que, com a sua autobiografia, Lemme se inscreve no rol de homens pertencentes a uma elite letrada que legaram suas ideias à posteridade.

Conforme será possível notar no primeiro capítulo deste trabalho, a análise retórica de qualquer discurso torna-se completa somente quando permite compreender a audiência a que se dirige. No caso da narrativa memorialística de Lemme, seria preciso, portanto, investigar as disposições de seus supostos leitores, os educadores situados no contexto da década de 1980, quando as Memórias foram publicadas. Em consonância com o projeto que originou esta dissertação, esse tema não será desenvolvido, uma vez que para isto seria necessário estudar a conjuntura daquela época, o que extrapolaria as possibilidades desta pesquisa de mestrado. Mas o assunto será abordado nas considerações finais deste texto, a título de proporcionar algumas hipóteses de interpretação para futuras análises. 


\section{I - NARRATIVA MEMORIALÍSTICA E ANÁLISE RETÓRICA}

Este capítulo contém um exame da narrativa memorialística como fonte para o desenvolvimento de pesquisas historiográficas, apresentando autores que enaltecem o valor dessa metodologia, bem como pesquisadores que alertam para as dificuldades por ela impostas. Considerando esses dois aspectos, introduziremos a análise retórica como alternativa metodológica para a investigação de discursos constituídos por memórias. $\mathrm{O}$ objetivo destas páginas é apresentar os referenciais teóricos e metodológicos que permitirão analisar o discurso de Paschoal Lemme, o que será feito no quarto capítulo desta dissertação, considerando o material apresentado nos capítulos segundo e terceiro.

\section{A relevância da narrativa memorialística}

A utilização de memórias individuais e coletivas, orais ou escritas, como fontes em pesquisas historiográficas ganhou credibilidade no cenário internacional durante o século XX, com o gradual reconhecimento da história oral como campo de investigação propício para desvendar o passado. A história oral firmou-se como "movimento e prática" nas décadas de 1960 e 1970, tendo como um de seus pilares os debates concernentes ao vínculo entre memória e história, cuja relevância tem sido crescente entre os pesquisadores, em especial entre os historiadores (THOMSON; FRISCH; HAMILTON, 2006, p. 66). No Brasil, tais debates começaram nos anos de 1970, alcançando notável adesão na década de 1990 (AMADO; FERREIRA, 2006, p. 9).

Levi (2006, p. 170-171) analisa que no final do século XVIII chegou-se a duvidar do valor das autobiografias, o que foi ocasionado pela avaliação de que “personagem social” e "percepção de si” são elementos totalmente dissociados. Naquela época, no entanto, já havia defensores do discurso memorialístico, como Jean-Jacques Rousseau, por exemplo, que acreditava na possibilidade de "narrar a vida de um homem" de maneira "totalmente verídica". Ao escrever sua autobiografia, Rousseau constatou não a impossibilidade de contar sua própria história, mas a de fazê-lo sem deformação ou alteração (idem, p. 172).

Sobre a valorização de biografias e autobiografias ao longo da História, Levi (2006, p. 167) afirma que os dias de hoje constituem uma "fase intermediária", pois esse tipo de obra encontra-se no "centro das preocupações dos historiadores", sem que se possa, no entanto, afastá-las totalmente de ambiguidades. Para Momigliano (1974, apud 
LEVI, 2006, p. 167), ${ }^{2}$ tais ambiguidades são fecundas, fazendo da biografia uma poderosa ferramenta de pesquisa; trata-se de um instrumento aberto a "todo tipo de problemas dentro de fronteiras bem definidas" (MOMIGLIANO, 1984, apud LEVI, 2006, p. 167-168). ${ }^{3}$

Para alguns autores, as narrativas memorialísticas representam importante contribuição para a pesquisa historiográfica porque a memória, como afirma Le Goff (2003, p. 419), possibilita "conservar certas informações", constituindo um "conjunto de funções psíquicas" que permite ao homem "atualizar impressões ou informações passadas, ou que ele representa como passadas”. Le Goff (idem, p. 471) ressalta que na memória "cresce a história, que por sua vez a alimenta"; a memória busca "salvar o passado para servir ao presente e ao futuro". Para Levi (2006, p. 168), tais narrativas constituem um "canal privilegiado através do qual os questionamentos e as técnicas peculiares da literatura se transmitem à historiografia".

Nunes (2011, p. 73) acrescenta que a utilização de biografias e autobiografias na pesquisa historiográfica é essencial para romper a tendência ao "excesso de coerência" que se nota no discurso histórico, permitindo indagar não somente o passado, mas, primordialmente, "todas as outras possibilidades perdidas", a exemplo daquelas que não se realizaram como futuro. A atenção dos pesquisadores à "dimensão coletiva da experiência histórica" e a sua "reflexão sobre os destinos individuais" fazem parte de um movimento que pretende contrapor-se à "insatisfação com os conceitos totalizantes" que reduzem "as ações humanas a subprodutos das forças produtivas e culturais" (idem, p. 67).

Na avaliação de Loriga (1998, p. 248), biografias e autobiografias possuem "valor democrático", pois a sua intenção mais profunda é "refletir sobre tudo o que a generalização" histórica não alcança. Albert (1993, apud SOUSA, 1998, p. 31) destaca que a obra autobiográfica pertence a "um conjunto diversificado de produções sobre si", sendo uma das "mais nobres modalidades da escritura identitária", uma vez que constitui um ato de autorrevelação, um "recurso privilegiado de tomada de consciência de si mesmo" que viabiliza um nível de "elaboração lógica e de reflexibilidade" que

\footnotetext{
${ }^{2}$ MOMIGLIANO, Arnaldo. Lo Sviluppo della biografia greca. Torino, 1974.

${ }^{3}$ MOMIGLIANO, Arnaldo. Storocismo rivisitato. In: Fondamenti della storia antica. Torino, 1984.

${ }^{4}$ ALBERT, Jean-Pierre. Etre soi: écritures ordinaries de l'identité. In: CHAUDRON, Martine; SINGLY, François de (Orgs.). Identité, lecture, écriture. Paris: Centre Georges Pompinou, Bibliothèque Publique d'Information, 1993.
} 
ultrapassa a potencialidade da expressão oral. As narrativas memorialísticas representam uma "extensão da pessoa" que se revela tanto para si mesma quanto para os outros (idem, p. 58).

Tomando por base as ideias de Boaventura Santos, Delgado (2010, p. 62) acrescenta que a memória, "fonte para expressão de etnicidades, línguas, particularismos, racismos, sexismos e processos culturais", exprime a "multiculturalidade" que é "inerente à organização humana em sociedade"; sua recuperação altera positivamente a "potencialidade de autoconhecimento no conjunto de organizações sociais pluralistas". Sendo assim, as pesquisas que utilizam a memória como matéria-prima contribuem para a "relativização das interpretações" que visam "sobrevalorizar as totalidades em detrimento das especificidades e dos particularismos". Ao exprimirem a "diversidade narrativa e representativa", tais pesquisas podem atuar como "suportes para a construção da justa memória", capacitando o pesquisador a fugir da "hegemonia de uma visão de passado utilitário e das amnésias impostas" que impedem a incorporação de diferenças.

Para Delgado (2010, p. 43), o valor das narrativas memorialísticas reside tanto na possibilidade de "preservação" quanto de "transmissão de heranças identitárias e tradições". Essas narrativas são relevantes para a historiografia como "estilo de transmissão, de geração para geração, das experiências mais simples da vida cotidiana" e dos "grandes eventos" da história humana; pertencem à "arte de contar", isto é, "traduzir em palavras os registros da memória" e da "consciência da memória no tempo". A "natureza dinâmica" desse "gênero específico do discurso" o torna integrante da cultura de diversas comunidades, englobando suas "dimensões materiais, sociais, simbólicas e imaginárias".

Segundo Khoury (2000, p. 131), as narrativas memorialísticas são "plenas de dimensão temporal"; sua principal fonte é a experiência, pois em suas narrativas as pessoas sempre se remetem ao passado por meio de "imagens" imbricadas na "consciência de si mesmas, ou daquilo que elas próprias aspiram ser na realidade social". Delgado (2010, p. 43) ressalta que tais narrativas trazem a "potencialidade de fazer viajar o ouvinte através da viagem narrada", apresentando um "potencial inesgotável” por se constituírem como "fontes para construção do conhecimento histórico"; por esse motivo, trabalhar com memórias é "caminhar por um terreno fértill". É essencial, no entanto, que o pesquisador tenha "sensibilidade, criatividade, e ética", 
além de "conhecimento histórico consistente sobre o tema", pois se trata de um caminho naturalmente "escorregadio" (idem, p. 64).

Delgado (2010, p. 44) considera ainda que as narrativas memorialísticas são "traduções dos registros das experiências retidas", possuindo "a força da tradição" e expondo "o poder das transformações". Assim, "narrativas, sujeitos, memórias, histórias e identidades" são a "humanidade em movimento, olhares que permeiam tempos heterogêneos", a "história em construção" a partir de "memórias que falam". A História e a narrativa, bem como a História e a memória, alimentam-se mutuamente. É impossível oferecer uma definição acabada de memória, sendo incontáveis as tentativas de fazê-lo; cada autor utiliza a que mais condiz com seus pressupostos (idem, p. 37).

Pinto (1998, p. 307) conceitua memória como "lugar do refúgio, meio história, meio ficção", um "universo marginal que permite a manifestação continuamente atualizada do passado". Chauí (1995, p. 125) entende memória como "evocação do passado", como a "capacidade humana de reter e guardar o tempo que se foi, salvando-o da perda total"; memória é também uma "forma de conhecimento e experiência", desenhando um "caminho possível para que sujeitos percorram os tempos de sua vida". Ferreira (2000, p. 111), por sua vez, sustenta que memória é "a construção do passado pautada por emoções e vivências", sendo, portanto, "flexível"; os "eventos são lembrados à luz da experiência subsequente", bem como das "necessidades do presente".

Diante dessa multiplicidade conceitual, Delgado (2010, p. 38) defende que memória é a "base construtora de identidades e solidificadora de consciências individuais e coletivas", não apenas o "ato de recordar", pois evidencia "os fundamentos da existência, fazendo com que a experiência existencial" seja integrada ao "cotidiano, fornecendo-lhe significado" e impedindo que "a humanidade perca raízes, lastros e identidades”. Ligada à vida por meio da linguagem, a narrativa viabiliza que a memória apresente "uma de suas mais ricas expressões". Para Ricouer (1997, p. 379-380), essa linguagem é a "grande instituição que contém as coisas já ditas, ouvidas e recebidas".

Delgado também ressalta que "conhecer o passado é uma façanha tão extraordinária quanto alcançar o infinito", ou "contar estrelas", uma vez que esse conhecimento, "mesmo quando bem documentado", pode ser "fugidio e amplo", devido à sua "extraordinária dimensão e variedade de situações". A busca pela recomposição integral do passado é uma operação cheia de dificuldades, mas possível de ser enfrentada por meio de variados documentos e diversas fontes, conjunto do qual fazem 
parte os “objetos biográficos”. Essa é tarefa da História e da memória, considerando que a sua maior contribuição é "evitar que o ser humano perca referências fundamentais à construção de identidades coletivas", as quais, embora estejam "sempre em curso", são "esteios fundamentais" para o "autoconhecimento do homem como sujeito de sua história" (DELGADO, 2010, p. 36). Mesmo passíveis de distinção, História e memória participam de uma "substância comum", pois são "antídotos do esquecimento, fontes da imortalidade" (idem, p. 42).

Alberti (2004, p. 33) entende que "conceber o passado não é apenas selá-lo sob determinado significado"; não é somente elaborar uma interpretação, mas também "negociar e disputar significados e desencadear ações" presentes na memória dos sujeitos que vivenciaram fatos e processos já ocorridos. As narrativas memorialísticas trazem dados e informações que não podem ser acessados por outros métodos de investigação, mas, ao lidar com processos mnemônicos, o historiador precisa ter consciência de que adentra um território que é propriedade de determinado autor, uma vez que a memória é um "elemento essencial do que se costuma chamar identidade, individual ou coletiva"; compreender a memória é uma das "atividades fundamentais dos indivíduos e das sociedades de hoje, na febre e na angústia” (LE GOFF, 2003, p. 469).

Delgado (2010, p. 16) analisa que a memória é um "cabedal infinito" em que "múltiplas variáveis - temporais, topográficas, individuais, coletivas - dialogam entre si, muitas vezes revelando lembranças", as quais, em certas ocasiões, surgem de modo explícito, ao passo que, em outras, aparecem veladamente, podendo até mesmo ser "ocultadas" por uma "camada protetora que o próprio ser humano cria" ao acreditar, "inconscientemente, que assim está se protegendo das dores, dos traumas e das emoções que marcaram sua vida". O "tempo da memória" vai além do "tempo da vida individual", encontrando-se com o "tempo da História", pois consiste em um amálgama de "lembranças de família, músicas, filmes, tradições, histórias escutadas e registradas". A "memória ativa" é um "recurso importante para transmissão de experiências consolidadas ao longo de diferentes temporalidades" (DELGADO, 2010, p. 17). A memória coletiva e a memória individual estão sempre associadas e são dotadas de poder, tanto o poder de esquecer quanto o de lembrar, o poder de omitir e o poder de silenciar (idem, p. 31).

Há autores que, ao caracterizarem a História como "produção intelectual do saber", acreditam que nesse campo opere um "processo cognitivo" capaz de destruir a 
"memória espontânea" (DELGADO, 2010, p. 70). Outros, como Guarinello (1994, p. 192), entendem que a contraposição entre memória e história é falsa, pois "a história enriquece as representações possíveis da memória coletiva". História e memória são "processos diferentes, mas não opostos", podendo ser vistos como "estimuladores recíprocos" que colaboram para que o ser humano, ao identificar-se como "sujeito construtor da História", reconheça a si mesmo como "construtor de seu presente e de seu futuro" (DELGADO, 2010, p. 70).

Delgado (2010, p. 37) também afirma que "tempo e espaço têm na memória sua salvação", pois sozinhos tais preceitos promovem confusões no que concerne ao "resgate das lembranças"; o "entrelaçamento com a memória" os transforma em verdadeiros "esteios das identidades, suportes do ser no mundo". Poulet (1992, p. 5455) endossa essa tese, ao destacar que, por obra da memória, “o tempo não está perdido, e se não está perdido, também o espaço não está". Assim, "ao lado do tempo reencontrado está o espaço reencontrado", ou, mais precisamente, "um espaço, enfim reencontrado, que se encontra e se descobre" graças ao "movimento desencadeado pela lembrança".

Alberti (2004, p. 40) sustenta que, ao estudar o passado e o presente, o pesquisador tem a meta de ultrapassar a "simples história do acontecimento", preocupando-se igualmente com a "história da memória desse acontecimento", uma vez que, segundo Frank (1992, apud ALBERTI, 2004, p. 40), "o acontecimento do passado dito 'objetivo' não basta para explicar o presente", fazendo-se necessário "acrescentarlhe o conhecimento da percepção presente do passado", e esse "presente do passado" é a própria memória. O estudo da memória, portanto, facilita a compreensão da identidade que a memória visa estruturar. Essa visão reafirma a ideia de que a memória "é também um fato" e, como tal, pode ser "objetivamente estudado".

Segundo Thomson, Frisch e Hamilton (2006, p. 74), a utilização corriqueira de documentos memorialísticos em estudos historiográficos revela um esforço para resgatar a experiência e a opinião de indivíduos que "normalmente permanecem invisíveis na documentação histórica convencional", buscando ver essas fontes como evidências. Essa iniciativa revela a intenção de fazer a história "de baixo para cima",

\footnotetext{
${ }^{5}$ FRANK, Robert. La mémoire et l'historie. In: VOLDMAN, Danièle. (Org.). La bouche de la vérité? La recherche historique et les sources orales. Cahiers de I'HTP, p. 65-72, 1992.
} 
destacando um "ângulo diferente de visão", mediante o uso de uma "noção mais ampla do próprio processo de reconceber perguntas e respostas históricas".

Para François (2006, p. 4), o trabalho pautado na história oral e, consequentemente, em fontes historiográficas alternativas, como são as memórias, tem o intuito de "dar atenção especial 'aos dominados', aos silenciados e aos excluídos da história", assim como "à historia do cotidiano e da vida privada, à história local e enraizada", firmando assim uma concepção de caráter inovador perante a abordagem convencional, em que tais questões são normalmente relegadas à margem.

Thomson, Frisch e Hamilton (2006, p. 77) acrescentam que alguns historiadores vão além de meramente "incorporar a memória à sua coleção de ferramentas, fontes, métodos e abordagens", preferindo situá-la no rol de "alternativas e resistências vernaculares ao poder estabelecido", como "objeto de manipulação ideológica hegemônica por parte das estruturas de poder cultural e político"; assim, a memória é, em "todas as suas formas e dimensões", uma verdadeira "dimensão da história", uma "história própria que pode ser estudada e explorada". O desenvolvimento da "história formal" está intrinsecamente ligado aos "processos da memória", pois a memória é uma "conexão viva entre o passado celebrado, o presente conturbado e um futuro" que demanda "complexas escolhas políticas em todos os níveis", desde, o "individual e familiar" até o "comunitário, estadual e nacional” (idem, p. 80).

Benjamin (1994, p. 210) avalia que a memória é a "mais épica de todas as faculdades", constituindo um "elo temporal dotado de poder, informação e representação". Para Grossi e Ferreira (2001, p. 31), a memória está “imbuída” de uma "vastidão de possibilidades", sendo, por isso mesmo, "infinitamente rica em suas manifestações"; trata-se de um "instrumento valioso para a construção de narrativas, que registram modos de frequentar o mundo".

\section{Controvérsias acerca da narrativa memorialística}

Mesmo considerando as inegáveis contribuições das memórias à pesquisa historiográfica, alguns autores apresentam objeções ao uso desse tipo de fonte no desenvolvimento de investigações dedicadas a esclarecer o passado, tendo em vista que as informações e os dados assim obtidos exprimem traços marcantes de subjetividade, sendo, em última instância, a expressão do ponto de vista de um narrador que, em boa parte dos casos, tem ou teve compromisso com os fatos descritos. Sobre essa questão, Le Goff $(2003$, p. 29) afirma que a história é "não só a projeção que o homem faz do 
presente no passado, mas a projeção da parte mais imaginária do seu presente"; é "a projeção no passado do futuro que ele escolheu", resultando assim em "uma históriadesejo às avessas".

Bourdieu (2006, p. 184-185), por sua vez, assinala que o "relato autobiográfico se baseia sempre, ou pelo menos em parte, na preocupação de dar sentido, de tornar razoável", como também na necessidade de "extrair uma lógica ao mesmo tempo retrospectiva e prospectiva, uma consistência e uma constância", e assim estabelecer "relações inteligíveis, como a do efeito à causa eficiente ou final, entre os estados sucessivos", os quais são "constituídos em etapas de um desenvolvimento necessário". As narrativas memorialísticas contêm uma inclinação do autor a ser "o ideólogo de sua própria vida", elegendo, "em função de uma intenção global, certos acontecimentos significativos e estabelecendo entre eles conexões para lhes dar coerência”.

Bourdieu (2006, p. 185) ressalta ainda que produzir uma "história de vida, tratar a vida como uma história", como se fosse "o relato coerente de uma sequência de acontecimentos com significado e direção, talvez seja conformar-se com uma ilusão retórica", ou seja, "uma representação comum da existência que toda uma tradição literária não deixou e não deixa de reforçar". Segundo Robbe-Grillet (1984, apud LEVI, 2006, p. 185), ${ }^{6}$ não é viável conceber a trajetória de vida como algo linear, pois o "real é descontínuo, formado de elementos justapostos sem razão", sendo "todos eles únicos e tanto mais difíceis de serem apreendidos" na medida em que "surgem de modo incessantemente imprevisto, fora de propósito, aleatório".

Thomson, Frisch e Hamilton (2006, p. 66) acrescentam que, para os "historiadores documentalistas tradicionais" da década de 1970, a memória não era considerada "confiável" como fonte histórica, pois se apresenta sempre "distorcida pela deterioração física e pela nostalgia da velhice", bem como pela "influência de versões coletivas e retrospectivas do passado". Levi (2006, p. 173) assinala que ainda hoje as biografias e autobiografias são motivo de intensa discussão quanto às suas possibilidades e impossibilidades. Evidenciando os problemas presentes nesse tipo de obra, alguns historiadores afirmam que seu principal entrave é constituído pela complexidade e subjetividade inerentes à identidade, conceito marcado por contradições concernentes ao fato de a sua formação ser "progressiva", nunca "linear"; a pessoa que narra tem inegáveis dificuldades com a definição de sua própria individualidade.

\footnotetext{
${ }^{6}$ ROBBE-GRILET, Alain. Le miroir qui revient. Paris: Minuit, 1984.
} 
Uma solução aventada para os problemas aqui indicados seria confrontar a narrativa autobiográfica com outros documentos de igual valor histórico, medida que, no entanto, significaria simplesmente interpor uma narrativa a outra, sem a garantia de que a nova fonte, chamada para confirmar ou infirmar a memória, não seja igualmente marcada pela subjetividade. Nessa vertente argumentativa, considera-se que a verdade histórica é sempre uma versão de fatos, pois as "estruturas de poder de uma sociedade", incluindo "o poder das categorias sociais e dos grupos dominantes", deixam "testemunhos suscetíveis de orientar a história num ou noutro sentido", e assim acabam por influenciar a construção de quaisquer documentos (LE GOFF, 2003, p. 110).

Segundo Delgado (2010, p. 56), a “construção de representações sobre o passado, que é imutável, mas que pode ser ressignificado", nada mais é do que uma “articulação, quase sempre marcada por disputas e por tensões", e assim a memória e o conhecimento histórico podem ser colocados a serviço de "diferentes senhores"; por isso, "não há neutralidade em qualquer forma de abordagem do passado". Chesneaux (1995, p. 24) analisa que os sujeitos escolhem seu passado, e a opção está longe de ser "inocente". Assim, a atitude de investigar o passado constitui um "procedimento ativo" importante para o "reconhecimento dos interesses convergentes ou divergentes, que integram a vida humana em constante movimento, em permanente construção histórica" (DELGADO, 2010, p. 56).

Seguindo esses raciocínios críticos, pode-se concluir que não há meios inquestionáveis para julgar a veracidade das memórias, mas é possível tentar compreender as narrativas memorialísticas por intermédio da elucidação do contexto em que são produzidas e publicadas. Bourdieu (2006, p. 190) entende que não é possível examinar uma trajetória de vida sem a construção prévia dos "estados sucessivos” em que ela se desenvolveu. O pesquisador deve se ocupar com "o conjunto de relações objetivas que uniram o agente considerado ao conjunto dos outros agentes envolvidos no mesmo campo e confrontados com o mesmo espaço dos possíveis”. Bourdieu acrescenta que a referida elaboração prévia do contexto diz respeito ao "conjunto das posições simultaneamente ocupadas" em determinado momento por uma "individualidade biológica e socialmente instituída", a qual oferece sustentação a um "conjunto de atributos e atribuições" que permitem ao agente intervir, como tal, em diversos campos.

Nessa mesma linha de pensamento, Levi (2006, p. 176) ressalta que a utilização de biografias e autobiografias como pano de fundo para trabalhos de pesquisa assenta-se 
na "hipótese implícita" de que "qualquer que seja a sua originalidade aparente, uma vida não pode ser compreendida unicamente através de seus desvios ou singularidades", fazendo-se relevante, portanto, evidenciar que "cada desvio aparente em relação às normas ocorre em um contexto histórico que o justifica". Dentro dessa abordagem, o pesquisador consegue "manter o equilíbrio entre a especificidade da trajetória individual e o sistema social como um todo".

Ao focalizar o contexto concernente a obras biográficas e autobiográficas, é preciso ter cautela para que o resultado da investigação não se estabeleça com rigidez, servindo de mero "pano de fundo imóvel" para explicar as obras que são objetos da pesquisa, como ocorre rotineiramente. Quando não se toma esse cuidado, as "trajetórias individuais" aparecem como que "arraigadas em um contexto", sem agir sobre ele e sem modificá-lo (LEVI, 2006, p. 176). Segundo Levi (idem, p. 169), associa-se, nessa abordagem equivocada, "uma cronologia ordenada, uma personalidade coerente e estável, ações sem inércia e decisões sem incertezas", de tal maneira que os "atores históricos" acabam obedecendo a um "modelo de racionalidade anacrônico e limitado".

Delgado (2010, p. 16) também destaca que o processo da memória contém tanto a "dimensão do tempo individual", que abarca a "vida privada e o roteiro biográfico", quanto a "dimensão do tempo coletivo", composta pelos âmbitos "social, nacional e internacional". Assim, os "sinais exteriores são referências e estímulos para o afloramento de lembranças e recordações individuais", os quais "constituem o ato de rememorar", que, por sua vez, tem estreita relação com os "quadros sociais da memória”. Para Maia e Arruda (2003, p. 21), a memória cruza “o particular e o global”, as instâncias individuais e as coletivas, "a intimidade e a história".

Bourdieu (2006, p. 189) afirma que a intenção de entender "uma vida como uma série única e por si suficiente de acontecimentos sucessivos", sem vínculo com nenhum outro elemento que não seja o indivíduo, é tão absurda quanto tentar explicar um trajeto de metrô sem associá-lo à rede à qual pertence, sem enxergar a sua integração com as estações que o cercam. Sendo assim, as ocorrências biográficas devem ser definidas em termos de "colocações e deslocamentos no espaço social", sempre de acordo com os diversos "estados sucessivos" que compõem "a estrutura de distribuição das diferentes espécies de capital que estão em jogo no campo considerado" (idem, p. 190).

Segundo Nunes (2011, p. 70), a concepção de Bourdieu acerca de biografias e autobiografias permite operar não somente com as experiências individuais, mas 
também com a "experiência social" do biografado, levando em conta as "determinações ligadas ao campo" a que pertencem tais experiências. Esse campo é constituído por "uma rede de relações objetivas entre posições", englobando "relações de dominação, subordinação, complementaridade" e, mesmo, “antagonismo", sendo cada posição definida sempre na "relação objetiva com outras". É por esse motivo que, segundo Nunes, Bourdieu defende que "uma caracterização do campo é condição prévia para a construção das trajetórias sociais".

Nunes (2011, p. 71-72) salienta ainda que a obra biográfica precisa ser entendida como "estrutura comunicativa, plural, ambígua, inacabada, aberta a múltiplos sentidos", para que o pesquisador não caia na "armadilha" corriqueira do "fechamento da compreensão biográfica”. Ao lidar com documentos biográficos e autobiográficos, é preciso estabelecer relações com os sujeitos estudados, o que se faz pela "mediação de objetos" que são os próprios textos por eles escritos. Contudo, deter-se inteiramente nesses textos pode conduzir à absolutização da mediação e à perda de sua historicidade, deixando em segundo plano a "historicidade da leitura". O pesquisador precisa ter em mente que o "sentido" de um texto é constituído por relações de forças que envolvem o "lugar social" tanto de quem o escreveu quanto de quem o lê.

Seguindo Bourdieu, Nunes (2011, p. 72) também considera que, no trabalho com biografias e autobiografias, é importante "ampliar as fronteiras do já conhecido", incluindo em tais relatos "as incoerências, as censuras, os caminhos escolhidos", bem como os "abandonados, as possibilidades recusadas, os fracassos e as dúvidas, as avaliações incorretas do campo e de suas relações de força, as disputas veladas ou explícitas". Sobre esse tema, Delgado (2010, p. 15) diz que o "passado espelhado no presente reproduz, através de narrativas, a dinâmica da vida pessoal", a qual mantém “conexão com processos coletivos". Por esse motivo, reconstituir essa dinâmica concorre para reconstituir o passado, de acordo com os preceitos de cada autor, o que envolve considerar "ênfases, lapsos, esquecimentos e omissões".

Utilizando os preceitos defendidos por Paul Veyne, Nunes (2011, p. 72) destaca que o pesquisador que trabalha com narrativas biográficas e autobiográficas precisa estar atento "à objetividade das práticas subjetivas e à possibilidade de elaborar certas constantes, que podem ser historicizadas". Le Goff (2003, p. 110) entende que "todo documento é um monumento" a ser "analisado, desestruturado, desmontado", pois "nenhum documento é inocente". Sejam "documentos conscientes ou inconscientes (traços deixados pelos homens sem a mínima intenção de legar um testemunho à 
posteridade)", os condicionantes da produção do documento devem ser estudados "minuciosamente". Os documentos só se tornam fontes históricas depois de serem submetidos a "tratamentos destinados a transformar sua função de mentira em confissão de verdade".

\section{A análise retórica como alternativa metodológica}

A partir das considerações feitas acima, concernentes aos aspectos positivos e problemáticos da narrativa memorialística, como também às alternativas apresentadas pelos autores examinados, podemos formular as seguintes conclusões: as memórias são documentos construídos por um autor que, em determinado momento da história, elabora uma narrativa sobre o passado, buscando manter coerência e conferir significado a fatos pretéritos; o intuito do memorialista consiste em apresentar a si mesmo, bem como os eventos narrados, perante determinado conjunto de leitores; mesmo adotando um estilo documental isento de valorações de natureza pessoal, o autor das memórias permeia sua narrativa com elementos subjetivos, próprios de quem tomou parte nos acontecimentos relatados; por isso, é imprescindível situar os relatos memorialísticos no contexto em que são produzidos e tornados públicos, considerando as circunstâncias que cercam o autor e também os leitores a quem a narrativa se destina.

Mediante essas considerações, entendemos ser necessário valorizar as memórias como fontes historiográficas e, ao mesmo tempo, encontrar recursos de investigação que contemplem a possibilidade de compreendê-las em seu contexto de produção e veiculação. Acreditamos que a análise retórica, tal qual adotada e desenvolvida pelo Grupo de Pesquisa Retórica e Argumentação na Pedagogia, possui instrumentos teóricos e metodológicos adequados a essas finalidades, uma vez que tal método abrange o estudo dos qualificativos (ethos) do autor - que na retórica se denomina orador -, envolvendo o contexto de enunciação e exposição do discurso; o discurso (logos) propriamente dito, que são as articulações lógicas e argumentativas empregadas no texto; e as disposições (pathos) intelectuais e emocionais dos leitores - que na retórica recebe o nome de auditório - a quem o orador se dirige.

A análise retórica não pretende emitir juízos valorativos sobre nenhum desses elementos, mas desvendar as estratégias argumentativas utilizadas pelo autor/orador na argumentação que desenvolve com o intuito de persuadir seus leitores/auditório e, assim, desencadear ações voltadas a manter ou a transformar determinada situação. A retórica concebe as fontes historiográficas como "títulos de provas", contrariando os 
preceitos irracionalistas e as críticas positivistas de que a historiografia, assim como a retórica, tem o intuito exclusivo de convencer, sendo sua única meta a eficácia, não a verdade (GINZBURG, 2002, p. 48). Ginzburg (idem, p. 61) ressalta que o principal objetivo de toda pessoa dedicada à pesquisa, o que inclui os historiadores, é descobrir a verdade; por essa razão, ao invés de serem "incompatíveis" com a retórica, as fontes historiográficas compõem o seu "núcleo fundamental" (idem, p. 63).

Ginzburg tece tais considerações à luz da filosofia de Aristóteles, que qualifica a retórica como "atividade que produz discursos persuasivos (pisteis)" (CUNHA, 2007, p. 75); trata-se de uma "metodologia da persuasão", uma "arte que analisa e define os procedimentos" utilizados pelo ser humano na busca por convencer seus semelhantes (REALE, 2002, p. 472). Para Berti (1998, p. 172-173), a retórica é um método voltado para "apreender o verdadeiro", baseando-se em "premissas conhecidas e compartilhadas", tanto por um interlocutor quanto por um auditório em determinadas situações.

A escolha da análise retórica como ferramenta de análise de discursos que veiculam proposições político-pedagógicas justifica-se por sua adequação a áreas que se encontram "abertas à deliberação e à discussão", como são as ciências humanas, em geral, e a pedagogia, em particular (CUNHA, 2010, p. 3). A metodologia retórica não pretende solucionar os embates teóricos e ideológicos que se fazem presentes nas ciências que compõem a pedagogia, mas apresentar elementos que favoreçam o diálogo entre as inúmeras abordagens dedicadas ao universo educacional (idem, p. 11).

Além das obras de Aristóteles, a análise retórica possui como fundamento os preceitos elaborados por autores vinculados ao movimento de revisão do pensamento aristoteleciano que teve início no século XX, com destaque para Chaïm Perelman, cujas ideias deram origem ao Tratado da argumentação (PERELMAN; OLBRECHTSTYTECA, 2005) e Stephen Toulmin, cujas contribuições encontram-se principalmente no livro Os usos do argumento (TOULMIN, 2001).

Perelman e Olbrechts-Tyteca apresentam a "nova retórica", na qual recuperam os preceitos expostos por Aristóteles acerca da dialética, tida como a "arte de raciocinar a partir de opiniões aceitas em geral", e os associam à teoria da argumentação. Ao contrário da retórica clássica, que privilegia a argumentação oral, os referidos autores focalizam textos impressos, a fim de compreender as estruturas do pensamento e da argumentação (SIRCILLI, 2006, p. 27). Os autores explicam que todo discurso é destinado a um auditório, inclusive o discurso escrito, o que é normalmente esquecido; 
devido à inexistência material de leitores, o escritor tende a acreditar que trabalha solitariamente em seu ofício, mas a elaboração do texto é sempre norteada, mesmo que inconscientemente, pela imagem de supostos leitores, uma vez que o discurso (logos) é sempre construído com vistas a uma audiência (PERELMAN; OLBRECHTSTYTECA, 2005, p. 7).

A metodologia retórica segue o pressuposto de que um texto, quando remetido à publicação, tem a função de viabilizar o diálogo do autor com seus eventuais leitores, o que o caracteriza como uma "peça de discurso", ou seja, um "conjunto de enunciados que constituem significados numa relação de interlocução", considerando uma audiência a ser mobilizada (CUNHA, 2005, p. 195). Cunha (2010, p. 3) afirma que o diálogo do autor com seus leitores, tendo em vista a persuasão, é o objetivo de todo discurso impresso, independentemente do gênero - científico, filosófico, didático etc. e do conteúdo da mensagem.

O exame de um texto por intermédio dessa metodologia privilegia o estudo do autor/orador e suas relações com os leitores/auditório, buscando revelar as circunstâncias históricas que envolvem esses dois elementos, o que denominamos contexto, ou seja, o "conjunto de condições concretas que une autor e leitores num vasto campo de ideias, experiências e condutas existentes no cenário da produção material e cultural da sociedade". É por meio desse estudo que se pode atribuir "sentido e veracidade" à análise do discurso (CUNHA, 2010, p. 16).

A análise de discursos utilizando essa abordagem investigativa tem o intuito de contribuir para que os leitores compreendam as estratégias discursivas a que são submetidos, o que, por sua vez, pode levar a posicionamentos mais esclarecidos acerca das ações a que tais leitores são chamados a praticar, sob a influência das teses contidas no texto. Segundo Perelman e Olbrechts-Tyteca (2005, p. 361-362), todo orador, ao relacionar-se com seu auditório, busca inspirar credibilidade, requisito necessário para que seu discurso seja valorizado. As informações biográficas que acompanham um texto cumprem essa função, oferecendo uma imagem, uma impressão - positiva, normalmente - sobre quem discursa.

As autobiografias constituem uma forma extremada de buscar a adesão e a consequente mobilização da audiência utilizando-se de elementos subjetivos, uma vez que veiculam uma "visão especial" de fatos ocorridos em determinado momento histórico, elaborados do ponto de vista único de uma pessoa (HÜTTENBERGER, 1992, 
apud ALBERTI, 2004, p. 34). ${ }^{7}$ Aquele que conta a sua própria história edifica não só uma imagem de si mesmo, mas também, agregado na mesma narrativa, um juízo acerca dos fatos que vivenciou, dos atos que praticou e das ideias que defendeu.

Quando o discurso remete à impressão de que a pessoa que o proferiu é digna de confiança, a persuasão ocorre pelo caráter do orador. Para Aristóteles (Retórica I, 1356a5), a confiança depositada no orador deve advir de seu próprio discurso e não de uma ideia prévia sobre o seu caráter; entretanto, o filósofo admite que, embora a integridade do que é dito seja importante, o caráter daquele que discursa é também um meio de persuasão. O orador pode persuadir seu auditório por meio do próprio discurso; nesse caso, é essencial que ele faça uma exposição do que é verdadeiro ou parece ser verdadeiro, tendo como alicerce o que é considerado persuasivo em cada situação particular; entretanto, quando a intenção é obter a adesão efetiva das disposições de seus ouvintes ou leitores, é necessário que seu discurso desperte emoções.

Para Perelman e Olbrechts-Tyteca (2005, p. 6), as paixões ou emoções são essenciais na persuasão, pois elas permitem atingir o objetivo maior da retórica, a “adesão dos espíritos”. Segundo Aristóteles (Retórica, II, 1378a20), as paixões são as “causas das mudanças nos nossos julgamentos", influenciando diretamente na forma como o auditório julga os fatos contidos em um discurso, seja ele oral ou escrito. Para argumentar de modo persuasivo, é essencial que o orador encontre "uma identidade onde, de início havia apenas antagonismo, diferença e contestação". Aquele que conhece as paixões consegue "classificar os homens", bem como escolher o melhor caminho para conduzi-los às ideias que julga serem corretas (MEYER, 2003, p. xxxviii).

Reale (2001, p. 195) define paixão como uma "perturbação da alma". Por estar ligada ao "corpo ou à parte da alma mais próxima da animalidade", ela é caracterizada como um impulso que precisa ser "moderado" e, até mesmo, “dominado". Narrativas memorialísticas, como a que será examinada no presente trabalho, trazem certa impulsividade, uma vez que as considerações construídas pelo memorialista acerca de seus atos e ideias são influenciadas diretamente por elementos subjetivos, os quais são permeados por paixões. No prefácio da primeira edição das memórias de Paschoal Lemme, Houaiss (1988, p. 14) afirma que, para os leitores interessados no "processo

7 HÜTTENBERGER, Peter. Überlegunger zur Theorie der Quellen. In: RUSINEK, Bern-A; ACKERMANN, Volker; ENGELBRECHT, Jörg (Orgs.). Einführung in die Interpretation historischer Quellen. Shwerpunkt: Neuzeit. Paterborn, Ferdinand Shöning, 1992. 
educacional brasileiro", a autobiografia é a "forma por excelência"; na autobiografia examinada, encontram-se "todos os impulsos generosos que animaram Paschoal e seus companheiros nesta empreitada, repito-o, sacrossanta", cujo intuito era cumprir seu compromisso com a educação. Segundo Houaiss, é impossível não notar que da obra de Lemme "emerge paixão".

As narrativas memorialísticas podem apresentar certo teor de imoderação por serem escritas, muitas vezes, em situações em que o autor busca persuadir determinada audiência acerca de suas ideias, as quais se encontram, normalmente, associadas a certo contexto. Sendo assim, é possível que a imoderação esteja presente na narrativa memorialística de Paschoal Lemme, visto que a obra foi escrita em um momento, a década de 1980, em que o suposto auditório a ser mobilizado - os intelectuais ligados à educação - estavam buscando meios para reorganizar o ideário educacional, e o autor, por sua vez, procurava interferir nas disposições intelectuais e emocionais de seus ouvintes, buscando persuadi-los de que as mudanças sociais devem anteceder a renovação educacional, não o contrário, como defendiam os intelectuais liberais.

As paixões apresentadas por Aristóteles na Retórica (II, 1378a20) estão ordenadas em sete pares, cada qual apresentando uma paixão e seu oposto: tranquilidade e cólera; amor e ódio; confiança e medo; pudor e despudor; benevolência e inveja; compaixão e indignação; emulação e desprezo. Souza (2014, p. 29) considera que as primeiras paixões de cada par inspiram sentimentos "positivos", tendo por objetivo despertar a credibilidade do auditório perante os fatos narrados; as segundas, por sua vez, inspiram sentimentos "negativos", visando despertar contrariedade pelos fatos narrados. No quarto capítulo deste trabalho, ao analisar as memórias de Paschoal Lemme, serão apresentadas algumas dessas paixões, visando mostrar os sentimentos que a narrativa do orador pode gerar em seus leitores. 


\section{II - O ETHOS DO ORADOR}

Toda narrativa de fatos pretéritos é feita com o olhar do presente, e esse olhar, impregnado pelas problemáticas da atualidade, tende a conferir ao passado um sentido que é influenciado pelas necessidades e circunstâncias experimentadas pelo narrador. Sendo assim, podemos entender a obra memorialística de Paschoal Lemme como um esforço destinado a dar coerência ao que foi por ele vivido, contribuindo, assim, para construir, no momento em que o relato se desenvolveu, certa imagem de quem foi e de quem é o autor - o que, nos termos da análise retórica, denominamos ethos do orador.

Os episódios descritos por Lemme nos três primeiros volumes de suas memórias vão de sua infância ao ano de 1982, oferecendo ao leitor a possibilidade de visualizar um homem que, desde muito cedo, desenvolveu sensível interesse por assuntos educacionais, e que, no decorrer de sua vida, procurou meios para transformar a situação vigente em prol de renovar as práticas educativas, movido por uma visão crítica da ordem social.

A narrativa do autor deixa transparecer a imagem de uma pessoa obstinada, dotada de princípios inabaláveis pautados na necessidade imperativa de alterar a realidade vigente, o que caracteriza uma forma de messianismo - termo que remete à ideia de missão, tarefa a ser cumprida por alguém dotado de qualidades excepcionais, um homem predestinado.

\section{Os primeiros anos de uma trajetória missionária}

Filho do dentista Antônio Lemme e da dona de casa Maria do Nascimento Lemme, Paschoal nasceu no dia 12 de novembro de 1904 no Méier, bairro do antigo Distrito Federal. Mesmo com alguns momentos de solidão, o menino teve uma infância tranquila, típica da época. Por ser tímido, tinha os livros como companheiros nos momentos em que não auxiliava o pai no consultório dentário. Desde muito cedo, seus interesses giravam em torno de questões educacionais, enquanto o desejo da família era vê-lo formado em odontologia.

O autor aborda seus tempos de criança, dos quais afirma sentir saudades por serem tão diferentes dos dias de hoje: "Aqueles bons tempos que não voltam mais, tragados pela tecnologia, pelo 'progresso', pela angústia, pela vida que passa e não é vivida" (LEMME, 1988a, p. 29). Imerso na beleza daqueles tempos, Lemme (idem, p. 
36) analisa criticamente os dias atuais: "Fala-se tanto hoje em 'criatividade' e tudo parece organizado para formar crianças robôs".

Sua adolescência foi marcada por um comportamento introspectivo resultante das "contingências dos hábitos e práticas da educação da época e também da essência repressiva da própria civilização" (LEMME, 1988a, p. 92). Ele considera impossível esquecer os ensinamentos que então obteve, os quais visavam a "um aproveitamento e desenvolvimento de todos os aspectos da personalidade de cada um", com o objetivo de banir, de todas as formas, pensamentos e atitudes indesejáveis. Apesar das circunstâncias típicas da época, afirma ter sido conquistado pelos temas da educação, sendo despertado pelo desejo de lutar por aquilo em que acreditava (idem, p. 105).

Lemme (1988a, p. 93) informa que, na juventude, desenvolveu notável sede por mudanças na vida do país, principalmente após o dia 5 de julho de 1922, quando ocorreu o "primeiro levante dos 'tenentes', debelado por Epitáfio Pessoa"; e também após 1924, quando se deu o segundo levante, do qual resultou a "lendária Coluna Prestes". O autor ressalta que, mesmo jovem, possuía grande interesse e preocupação por assuntos referentes à política e à educação brasileiras.

Desde a infância, e mesmo quando adulto, diz ter sofrido expressiva influência paterna, inclusive em questões religiosas. Lemme (1988a, p. 55) herdou do pai o “interesse pela coisa pública e pelos destinos da pátria de adoção, seu espírito progressista e liberal, seu anticlericalismo, no sentido de não permitir qualquer manifestação de obscurantismo", o que o levou a compreender a importância de lutar por aquilo em que se acredita. Afirma não ter se tornado adepto do espiritismo como o pai, mas certos momentos de sua narrativa mostram a marca dos preceitos gerais dessa religião, particularmente quando são utilizados termos que remetem a predestinação, vocação e missão.

Lemme parece ver a si mesmo como predestinado a lidar com temas relativos à educação. Sua paixão e seu destino estavam no contato com os livros, com a sala de aula, no universo educacional, não na odontologia, em meio a instrumentos, medos e aflições, conforme presenciava todos os dias no consultório do pai. Ele afirma que, ainda jovem, descobriu sua "aptidão", sua "vocação" para ser professor; e foi diante de tal certeza que ele se voltou para o magistério, enfrentando preconceitos tanto de ordem familiar quanto social, pois se tratava de uma profissão essencialmente feminina, naquela época (LEMME, 1988a, p. 113-114). 
Lemme (1988a, p. 99) conta que a descoberta de sua "vocação" ocorreu devido à influência do professor Teófilo Moreira da Costa, homem de origem modesta, com visível "vocação, intuição e dedicação" para o ensino, que lhe ministrou aulas de Língua Nacional durante a infância na Escola Profissional Visconde de Cairú, no Distrito Federal. Adepto dos preceitos da "escola ativa", o professor Teófilo realizava um trabalho semelhante ao de Pestalozzi e de Makarenko, desenvolvendo um trabalho inovador durante os anos de 1910 e 1920 (LEMME, 1988a, p. 110). Foi Teófilo "quem detectou com mais segurança minhas preferências, aptidões ou "vocação", lembra o autor; em resposta à interpelação do pai sobre o que desejava ser, respondia de pronto, inspirado naquele mestre: “Se não for professor, não serei mais nada!” (idem, p. 113114).

Diante da escolha pelo magistério, Lemme (1988a, p. 111) se recorda: "fui preparado pelo meu professor Teófilo para os exames de admissão na Escola Normal do Distrito Federal”, pois “creio que [ele] descobrira em mim, não sei como, algumas qualidades e condições para seguir a carreira que abraçara e desempenhava com tanta dedicação". O autor trabalhou como professor naquela mesma escola, ao lado de seu mestre, entre os anos de 1927 e 1928. Mesmo após a morte do querido professor, nunca se esqueceu da influência exercida por ele sobre a sua formação, sobrepujando os esforços de seu pai para que seguisse a carreira da odontologia (idem, p. 113-114).

A opção pelo magistério transformou Lemme (1988a, p. 170) na "ovelha negra" da família, pois "tresmalhara do redil da arte dentária, para abraçar uma atividade que não se apoiava em qualquer tradição da família". Somava-se o fato de que "professor era, na prática, um funcionário público, e essa condição não gozava de muito bom conceito"; para seus pais, "profissões realmente dignas eram aquelas que se conquistavam e se exerciam por esforço próprio, livremente, e sem os favores dos governos"; tal "preconceito provinha talvez da circunstância dos cargos do "serviço público' serem naqueles tempos obtidos, quase todos, por apadrinhamento político”, o que não era "digno de um Lemme".

O autor chegou a ingressar no curso de engenharia, pois possuía "certo gosto pela construção civil" também por influência de seu pai; mas "não se tratava propriamente de uma vocação muito nítida". Lemme afirma que sua "vocação" era mesmo "para o magistério, para o ensino" (LEMME, 1988a, p. 162). A conquista do diploma na Escola Normal do antigo Distrito Federal, em 1924, foi o primeiro passo para cumprir essa vocação. Aquele momento foi "sem dúvida, como se pode imaginar, 
de intensa felicidade" - a aquisição "desse documento marcava uma etapa decisiva de minha vida, que se iniciava modesta, mas que representava uma conquista, devida exclusivamente ao meu esforço e à minha determinação: enfim era professor!" (idem, p. 174).

Pouco depois, Lemme foi nomeado professor de matemática em uma escola pública do Distrito Federal. O responsável pela administração do ensino era Carneiro Leão, que vinha introduzindo importantes medidas para a renovação do ensino, mas a situação geral não agradava a Lemme (1988b, p. 19): os inspetores escolares eram “movidos por um sentimento negativo de 'bairrismo' que sempre existiu entre o Rio de Janeiro e São Paulo", causando desânimo inclusive naqueles que buscavam inovações. Contudo, Lemme (idem, p. 17) elogia o conjunto das reformas então introduzidas, apesar de sua aparência "muito modesta".

Naquele mesmo ano foi fundada no Distrito Federal a Associação Brasileira de Educação, ABE, que Lemme (1988b, p. 99) qualifica como "uma agremiação de educadores que deveria desempenhar um papel da maior importância" no estudo e "no debate dos problemas mais relevantes de educação e do ensino em nosso país". Inicialmente formada por treze intelectuais e dirigida por seu principal idealizador, Heitor Lyra da Silva, a ABE foi importante polo de divulgação das ideias escolanovistas (CARVALHO, 1998, p. 57).

A concordância com essas novas ideias levou Lemme (1988b, p. 47) à ABE, filiando-se em 1926, o que lhe proporcionou "inestimáveis conhecimentos", pois se tratava, segundo ele, de uma "verdadeira universidade, pela qualidade de seus professores, expositores e conferencistas, brasileiros ou estrangeiros”. Sua intensa participação nas atividades da Associação o conduziu a integrar seu conselho diretor a partir de 1930.

Carvalho (1998, p. 61) explica que os sentimentos cívicos e nacionalistas vigentes no final da década de 1920 exaltavam a higiene, a moral, o trabalho e a educação como fatores essenciais para conduzir a nação brasileira aos ideais de Ordem e Progresso. Nesse contexto, a ABE tinha por objetivo principal promover "a difusão e o aperfeiçoamento da educação em todos os ramos e cooperar em todas as iniciativas" que contribuíssem, de alguma maneira, para a realização daquelas metas. Uma das formas de concretizar tal anseio eram as Conferências Nacionais de Educação, que passaram a ser realizadas naquela época (idem, p. 54-55). 
Quando Arthur Bernardes foi substituído por Washington Luís no governo do país, o novo presidente convidou Fernando de Azevedo para o cargo de Diretor Geral de Instrução Pública do Distrito Federal, por indicação do antigo diretor, Renato Jardim. Ao assumir a incumbência em 1927, engajado nos ideais renovadores daquela década, Azevedo empreendeu uma reforma do ensino visando superar os moldes vigentes e proporcionar condições para uma educação moderna, destinada a todo o povo brasileiro, o que viria garantir o necessário progresso do país (MATE, 2002, p. 62).

Lemme (1988b, p. 34) considera que as iniciativas de Azevedo foram essenciais para a criação de uma nova escola, pois instituíram uma administração repleta de "atividades criadoras" e um "trabalho completamente antiburocrático, antirrotineiro". Segundo analisa Nagle (2001, p. 134), o "otimismo pedagógico" e o "entusiasmo pela educação" eram traços característicos do ideário liberal ascendente na década de 1920, representando a busca pela formação do "novo homem brasileiro". As medidas reformistas do ensino e a disseminação da educação escolar eram vistas como meios para efetivar a ideia de que a educação era o verdadeiro "motor da história", a melhor maneira de colocar o Brasil "no caminho das grandes nações do mundo".

Paschoal Lemme integrou a equipe de Fernando de Azevedo, na qual assumiu diversas responsabilidades, sempre com o intuito de contribuir com as metas da renovação educacional. Em 1928, ainda como professor de curso elementar na Escola Profissional Visconde de Cairú, Lemme foi convidado a assumir o cargo de assessor do professor Jônatas Serrano na Subdiretoria Técnica, seção responsável pela elaboração e organização dos concursos públicos. Essa atividade, segundo o autor, era "tremendamente trabalhosa, mas de grande importância para a boa execução da Reforma", possibilitando-lhe maior proximidade com as personalidades "mais destacadas do magistério do país" (LEMME, 1988b, p. 38).

Em 1929, com a inauguração do novo prédio da Escola Normal, houve um remanejamento de cargos na Secretaria e no Gabinete do Diretor, fato que levou Lemme a ser transferido para o cargo de oficial de gabinete, sem qualquer prejuízo à sua função de assessor na Subdiretoria Técnica, aumentando, portanto, suas responsabilidades (LEMME, 1988b, p. 48). No início do ano de 1930, após a reforma da antiga escola de aperfeiçoamento “Amaro Cavalcanti”, Lemme (idem, p. 57-58) recebeu de Fernando de Azevedo uma nova incumbência, a de vice-diretor, responsável pela direção e organização dos cursos. Como a lei impunha que todo vice-diretor fosse também professor, o autor foi designado para ministrar matemática comercial no curso noturno. 
O relato de Lemme sobre a sua própria atuação em tantos cargos e diante de tantas responsabilidades revela um homem predestinado, persistente, decidido a lutar pela renovação do ensino ao lado dos intelectuais liberais, afirmando, assim, aquela sua vocação. Mesmo com o aumento gradativo de tarefas e a sobrecarga de trabalho que possuía durante sua participação na reforma liderada por Fernando de Azevedo, Lemme (1988b, p. 60) afirma: "a pedagogia, os problemas de educação e ensino tinham me conquistado definitivamente, e os concursos e os cursos que fiz posteriormente, fixaram-me de vez na 'profissão' de educador". Além disso, o contato com os profissionais participantes daquela reforma "fez com que passasse a ter por meta aprofundar os estudos dos problemas de educação e ensino", bem como "encontrar a direção que deveria adotar afinal, em definitivo, como carreira profissional e opção de vida" (LEMME, 1988a, p. 165).

Lemme (1988a, p. 166) conta que naquela época, entre os anos de 1922 e 1930, teve experiências que afetaram profundamente a sua vida profissional, em decorrência dos acontecimentos culturais e políticos então desencadeados, como a criação da $\mathrm{ABE}$ em 1924, a elaboração dos "primeiros cursos de aperfeiçoamento do magistério" que previam introduzir "novos métodos de ensino, oriundos do movimento de renovação da educação, conhecido como "escola nova", e o principal "marco histórico" do período o dia 5 de julho de 1922, quando a "repressão do governo Artur Bernardes" resultou na prisão de professores que foram "processados como elementos perturbadores da 'ordem pública"”. Segundo Lemme (1988a, p. 166) a proximidade com tais ocorrências fez com que sofresse a "influência desse ambiente de lutas patrióticas" que despertaram nele "o interesse por questões que diziam respeito ao futuro do povo brasileiro e ao progresso do País"; tais fatos o levaram a compreender que seu interesse pela educação não era oriundo somente de uma vocação, mas também de uma missão a ser cumprida.

Essa imagem de homem vocacionado, portador de uma missão, apresentada pelo autor em sua narrativa é ratificada por Antônio Houaiss, seu ex-aluno, no prefácio do primeiro volume da obra Memórias:

Paschoal Lemme era um respeitadíssimo (pelo menos, por nós, alunos) juveniadulto, marcado já pelo saber e conhecer e fazer, voltados integralmente para a missão sacrossanta (e o digo sem hipérbole) de educar: educar é encaminhar espíritos de um lugar para o outro, isto é, de um lugar em que não há senão natureza, para outro lugar em que a natureza é transformada em cultura. Paschoal Lemme era missão, paixão, devoção: cria fundamente que, em última análise, 
o homem é um ser de cultura, dessa coisa que só ele, homem, inventou, a saber, a capacidade/necessidade/fatalidade de marcar/transformar/modificar a natureza, para criar para si mesmo um universo em que ele, homem, possa ser cada vez mais homem mesmo. Punha-se Paschoal - pôs-se sempre - a serviço dessa causa, visão e cosmovisão, de tal modo que não era lícito a outrem ser céptico ante sua proposta e ação. Sua trajetória no serviço público foi uma batalha constante, inequívoca, corajosa, sacrificada, militante, em favor da escola brasileira. E a sua, então, era uma missão profética, ante os obstáculos que se lhe antepunham, a ele e a ela - a missão (HOUAISS, 1988, p. 11-12).

Ao finalizar o prefácio, Houaiss afirma: "O que deve ser realçado nesta obra é que paixão, devoção e dedicação emergem da pena rememorativa de Paschoal com toda a força da vida vivida", o que torna o seu texto "um documento palpitante de nossos malogros e esperanças na formação dos brasileiros do tempo passado e futuro" (HOUAISS, 1988, p. 14). Para Brandão (1999, p. 99), esse “depoimento de Houaiss, é testemunho do sentido de missão, que impregnou, como no caso do professor Teófilo, a atuação profissional de Lemme".

\section{O missionário reformista}

Lemme (1988b, p. 60) considera que a reforma comandada por Fernando de Azevedo entre 1927 e 1930 no Distrito Federal foi o ponto mais alto do "grande movimento de modernização do ensino e da educação no Brasil". No entanto, o golpe de estado desferido por Getúlio Vargas - a chamada Revolução de 1930 - levou os colaboradores da reforma a enfrentarem grandes dissabores, segundo Lemme (idem, p. 68), pois passaram a receber "um tratamento áspero do Governo Revolucionário". Mesmo os mais modestos participantes, como o próprio autor se considera, foram alvo de "represálias e sofrimentos", tendo que lidar com "um ambiente de verdadeiro revanchismo por parte de quantos se consideraram prejudicados" pelas medidas então instituídas (idem, p. 75-76).

Ao mesmo tempo em que se engajava "em todos os aspectos do movimento liderado por Fernando de Azevedo”, Lemme defendia ideias políticas e educacionais contrárias à da maioria dos demais atores da vida pública, razão pela qual passou por um "batismo de fogo" que atingiu sua vida pessoal, sendo demitido de seus cargos, restando-lhe apenas o vínculo como "professor adjunto de 2a classe" (LEMME, 1988b, p. 75-76). Diante do dever de sustentar a família que havia aumentado, Lemme (idem, 
p. 79) passou a ministrar aulas em uma escola primária no subúrbio de Bangu, fato que por pouco não o fez abandonar o serviço público.

$\mathrm{O}$ autor informa que o motivo dessas contrariedades foi o seu constante apoio às reformas de Azevedo. Recebeu críticas até mesmo de sua família, para quem as dificuldades financeiras enfrentadas eram fruto de sua proximidade com os renovadores da educação. Diante das dificuldades, ele pensou em "procurar outros caminhos que pudessem" lhe "proporcionar melhores perspectivas de vida"; contudo, confessa: "Não era fácil porém mudar de rumo" (LEMME, 1988b, p. 80).

A narrativa elaborada por Lemme mostra um posicionamento firme e decidido, uma vontade inquebrantável de realizar uma missão - lutar pela renovação do ensino e transformar o Brasil em um país mais justo para o povo. Mesmo naqueles "dias de amargura”, Lemme (1988b, p. 80) afirma: “Orgulhava-me da participação naquela obra que deveria ganhar uma significação histórica importante no processo de modernização do ensino no País"; devido aos "esforços, canseiras ou sacrifícios" que ele e seus companheiros empenharam naquela iniciativa, pondera que naquele momento a melhor saída era "contemporizar, mantendo, dentro do possível, o cargo público e esperar que novos tempos e novas oportunidades aparecessem".

Superando os dissabores, Lemme (1988b, p. 85) relata alguns bons momentos ocasionados pela Revolução de 1930, como a criação do Ministério da Educação e Saúde, pela lei $\mathrm{n}^{\circ}$ 19.402, em novembro daquele ano, no qual ele teve "uma pequena participação", sendo designado pelo ministro Francisco Campos para cuidar dos problemas relacionados ao ensino técnico-profissional. Também naquele ano, o autor passou a integrar o Conselho Diretor da Associação Brasileira de Educação.

Lemme (1988b, p. 63) conclui que a Revolução foi um "importante evento da história nacional", o que se explica pelo fato de ter despertado as "reações da juventude militar que se levantava em armas contra uma situação" que "não podia mais perdurar". Ele considera positivas certas mudanças então empreendidas nos campos da educação, da política, da economia e da vida social em geral, entendendo que a reforma de Fernando de Azevedo havia antecipado muitos dos "anseios e propósitos da Revolução, como frequentemente tem acontecido na história da humanidade: a luta das ideias antecedendo a luta das armas" (idem, p. 80).

Devido às frustrações ocasionadas pela Revolução, em 1931 Lemme tentou conduzir sua vida por novos rumos, projetando em parceria com a amiga Julieta Arruda, professora do magistério primário, um colégio que agregaria "as aquisições mais 
recentes da chamada "escola nova"' (LEMME, 1988b, p. 88-89). Lemme (idem, p. 90) conta que o intuito era criar "um estabelecimento que empregasse os métodos mais modernos de educação e ensino". Apesar de muito esforço, a escola - que foi denominada Instituto Brasileiro de Educação - fracassou, pois o ensino ali ministrado configurou-se "inteiramente fora dos padrões dos colégios comuns" (idem, p. 89).

Em dezembro de 1931, Paschoal Lemme participou da IV Conferência Nacional de Educação, promovida pela $\mathrm{ABE}$ no Rio de Janeiro, evento que foi palco de um pedido feito pelo Chefe do Governo Provisório, Getúlio Vargas, aos educadores ali presentes, para que estabelecessem o "sentido pedagógico" da Revolução, comprometendo-se, desse modo, com a "obra de reorganização do País”, tendo em vista os "problemas de educação e ensino" brasileiros (LEMME, 1988b, p. 102). Xavier (2004, p. 26) confirma que, naquela ocasião, Vargas pediu aos intelectuais que elaborassem uma "fórmula mais feliz" que visasse à "unidade da educação nacional”, a ser apoiada inteiramente pelas instâncias estatais.

Tal pedido deu origem ao Manifesto dos Pioneiros da Educação Nova, redigido por Fernando de Azevedo e publicado no ano de 1932, com o aval de um restrito grupo de intelectuais. Além de Paschoal Lemme, assinaram o documento Anísio Teixeira, Lourenço Filho, Afrânio Peixoto, Roquete Pinto, Cecília Meireles, Hermes Lima, Nóbrega da Cunha, Edgar Süssekind de Mendonça, Armanda Álvaro Alberto, Venâncio Filho, C. Delgado de Carvalho, Frota Pessoa, Raul Briquet, Sampaio Dória, Noemi Silveira, Atílio Vivacqua, Júlio de Mesquita Filho, Mario Casasanta, A. Almeida Júnior, J.P.Fontenelle, Roldão Lopes de Barros, Paulo Maranhão, Garcia de Rezende e Raul Gomes (XAVIER, 2004, p. 27).

Tendo como título original "A Reconstrução Educacional no Brasil”, acompanhado do subtítulo "ao povo e ao governo", o Manifesto continha "diretrizes para uma política educacional", apresentando um texto "claramente matizado pelas ideias defendidas pelos renovadores" de tendência liberal (MATE, 2002, p. 133-134). Apesar de as concepções ideológicas dos signatários não serem idênticas, todos eram adeptos da "perspectiva escolanovista" e voltados para os mesmos ideais, visando à "reconstrução de uma nação democrática" por intermédio da educação (XAVIER, 2004, p. 27). O Manifesto veiculava a ideia de que a "escola democrática" deveria operar como "centro irradiador de uma nova forma de organizar a sociedade" (idem, p. 29).

Segundo o relato de Paschoal Lemme (1988b, p. 113), mesmo sendo o mais jovem dentre os signatários, ele teve "participação ativa no aparecimento desse 
documento", colaborando no recolhimento das assinaturas de algumas personalidades, pois concordava inteiramente com as ideias expressas no texto. Lemme (idem, p. 114115) avalia que o Manifesto foi "o único documento claro e preciso" no setor da educação, tendo em vista "toda aquela confusão que se estabeleceu nos primeiros tempos que se seguiram à instalação da $2^{\text {a }}$ República”.

O Manifesto renovou o ânimo de Lemme (1988b, p. 113-114): "Via-me transportado àqueles bons tempos" da administração de Azevedo, "em que as preocupações materiais eram postas em segundo plano" diante de "nossos deveres perante os compromissos que assumíramos com a causa pública"; foi recuperado o valor do "desempenho de nossas funções de administradores do ensino e propugnadores de novos caminhos para educação do povo brasileiro". Lemme (idem, p. 119) considera que seu envolvimento com os fatos em torno do Manifesto foi um marco de sua carreira profissional, pois naquele momento fez "a definitiva opção de servir ao País no setor da educação e do ensino", conferindo, consequentemente, mais firmeza à sua missão.

$\mathrm{O}$ autor conta que, na mesma época, participou de outro momento relevante na história da educação brasileira, igualmente significativo em sua trajetória profissional. Entre os anos de 1931 e 1935, ocorreu no Distrito Federal a reforma do ensino comandada por Anísio Teixeira, a qual, segundo Pagni (2008, p. 26), teve por objetivo principal a defesa de uma "educação laica, pública e gratuita, como meio de promoção da democracia", dando continuidade às metas de Fernando de Azevedo. Paschoal Lemme (1988b, p. 134) considera que aquela foi "a mais criativa, corajosa e também controvertida administração de ensino" já vista no país.

Assessor de Teixeira, Lemme (1988b, p. 145) realizava simultaneamente a função de professor na Escola Normal, assumindo também a "seção de matemática, matemática aplicada e estatística" nas escolas técnicas secundárias. Em 1933, Celso Kelly, Diretor de Instrução Pública do Estado Rio de Janeiro, promoveu um concurso público para os cargos da Inspetoria de Ensino, os quais, até então, eram preenchidos em atendimento a interesses políticos (BRANDÃO, 2003, p. 68). Paschoal Lemme (1988b, p. 181) diz que, apesar de todas as tarefas que já desempenhava, foi um dos vinte e seis aprovados naquele concurso, assumindo assim mais uma incumbência. A principal função dos inspetores era visitar as escolas sob a sua responsabilidade, registrando um termo descritivo das condições de cada estabelecimento. Ao perceberem que tais visitas tinham caráter meramente burocrático, os novos inspetores, dentre os 
quais Paschoal Lemme, tomaram a iniciativa de ministrar cursos de aperfeiçoamento para os professores.

\section{Revezes e êxitos do missionário}

A promulgação da Constituição de 1934 trouxe um revés na trajetória ascendente de Lemme (1988b, p. 198), pois, segundo ele, permitiu a reintrodução da prática de ocupação de cargos públicos mediante favores políticos. Assim, os antigos inspetores escolares retomaram suas funções, ao passo que os novos passaram a ser tratados "de maneira ríspida e até descortês". O autor observa que "o novo Governo estava completamente envolvido pelos elementos interessados em destruir o trabalho" que os novos inspetores vinham realizando, com a justificativa de que vicejava entre eles um pensamento de esquerda, devendo, por isso, ser afastados da Inspetoria de Ensino. Lemme (idem, p. 217) afirma que naquela época era visto como um "intelectual de esquerda", devido à sua opção pelas teses da filosofia marxista; entretanto nunca esteve filiado "a qualquer organização política, nem desenvolvia qualquer atividade partidária militante".

$\mathrm{Na}$ busca por conter os ânimos exaltados com a situação, Paschoal Lemme e outro inspetor, o médico sanitarista Valério Konder, redigiram e publicaram dois manifestos - A Reconstrução Educacional no Estado do Rio de Janeiro e Os Inspetores de Ensino do Estado do Rio de Janeiro ao Magistério e à Sociedade Fluminense - com o intuito de explicar as atividades dos novos inspetores à opinião pública. Segundo Brandão (2003, p. 68), esses documentos tinham como finalidade delegar à "sociedade fluminense" e ao "magistério" a "tarefa de reconstrução educacional e social", excluindo, consequentemente, o "governo da condição de interlocutor explícito", a fim de viabilizar uma verdadeira "transformação pedagógica".

Em 1935, Lemme (1988b, p. 163) assumiu a Chefia da Superintendência de Educação Secundária Geral e Técnica e do Ensino de Extensão, até então ocupada por Farias Góes, de quem ele era assistente. O órgão foi reestruturado, aumentando consideravelmente a sua abrangência, pois passou a englobar também o ensino elementar para adultos, até então alocado no Departamento de Ensino Primário.

Aquele momento, que aparentava ser de progresso na trajetória profissional de Paschoal Lemme, revelou, porém, novas dificuldades. Os anos de 1935 e 1936 foram especialmente conturbados na esfera política, prenunciando o novo golpe de estado que viria em 1937. Antes mesmo desse evento, o cenário brasileiro foi palco do movimento 
denominado Intentona Comunista, ocorrido em novembro de 1935, o qual trouxe "consequências gravíssimas para o povo brasileiro, que se prolongam até hoje"; Anísio Teixeira e seus colaboradores, dentre os quais o próprio autor, foram diretamente atingidos, comprometendo a continuidade da administração a que se dedicavam no Distrito Federal (LEMME, 1988b, p. 228).

Desde o início da década de 1930, o mundo assistia à ascensão do fascismo, primeiro na Itália com Mussolini, mais tarde na Alemanha com Hitler; buscava-se uma solução para os problemas políticos, econômicos e sociais que assolavam tais países. Em 1932, os ecos do fascismo ascendente no cenário internacional invadiram o Brasil; fundou-se em São Paulo a Ação Integralista Brasileira, que era uma versão do movimento criado por Mussolini, trazendo consigo os "mesmos símbolos, gestos e doutrinas"; a diferença estava na cor que representava o movimento, "ao invés de camisas pardas", utilizavam "a cor verde, substituindo a cruz suástica dos nazistas, pelo sigma grego". Naquela época, seus representantes “começaram a produzir uma copiosa literatura de propaganda", além de "realizar marchas e concentrações nas principais cidades do país"; as "ideias e práticas" por eles defendidas infiltraram-se "em alguns setores das forças armadas, especialmente em nossa Marinha de Guerra e nos hostes do clero católico" (LEMME, 1988b, p. 214).

Em meio à onda fascista, em 1935 fundou-se a Aliança Nacional Libertadora, ANL, "organização de esquerda, cujo núcleo propulsor era o Partido Comunista"; seu objetivo era a "luta contra o fascismo", assumindo uma posição "nacionalista, antiimperialista e contra o latifúndio", e afirmando que somente uma "revolução democrático-burguesa" com posterior adesão popular seria capaz de retirar países como o Brasil da condição de subdesenvolvidos e elevá-los a um patamar de franco desenvolvimento. A ANL recebeu a adesão de muitos setores da população, "políticos e intelectuais de prestígio", além de alguns "elementos da antiga corrente dos 'tenentistas"” oriundos do Exército e da Marinha (LEMME, 1988b, p. 215-216).

A cada dia aumentava o "choque das duas correntes" antagônicas; o conflito, que se iniciara no plano das ideias, agora invadia as ruas, produzindo confrontos violentos. "O governo Vargas não escondia sua simpatia pelos integralistas", cujas ideias cativaram também os "principais chefes militares, sustentáculos da ordem vigente"; a cada dia, a situação atingia proporções mais graves (LEMME, 1988b, p. 216). 
Mesmo a Aliança Nacional Libertadora tendo conseguido "expressivo apoio da classe média, operária e de intelectuais, ela pouco se fortaleceu", devido às “divergências internas entre os elementos comunistas e não comunistas e a própria infiltração policial". Em contrapartida, havia grande pressão ocasionada pela "marcha mundial para a direita", apresentando uma "política nazifascista cada vez mais agressiva", o que gerou fortes influências no governo e resultou em "severa repressão contra o movimento aliancista que acabou no fechamento da Aliança Nacional Libertadora". Esse acontecimento levou seus "elementos mais exaltados a cerrarem fileiras em torno do Partido Comunista, para tentarem uma solução pelas armas para o conflito, sob a liderança de Luís Carlos Prestes” (LEMME, 1988b, p. 216-217).

Lemme (1988b, p. 220) recorda que, no final de 1935, a "agitação política crescia cada vez mais; no dia 24 de novembro começaram a chegar as primeiras notícias da deflagração de um movimento armado de esquerda em Natal”, o qual resultou na “instalação de um governo 'popular-revolucionário’ no Estado do Rio Grande do Norte com a deposição de todas as autoridades constituídas"; no dia seguinte, "o levante se estendeu à Recife" e posteriormente no Rio de Janeiro. Conhecido como Intentona Comunista, o movimento foi contido pelas forças governistas em poucos dias; a difícil comunicação entre os esquerdistas ocasionou a sua consumação em dias diferentes nos referidos estados, contribuindo para que as revoltas fossem antecipadamente percebidas; além disso, a omissão popular também contribuiu para a fraca disseminação do movimento, que acabou ocorrendo somente nos quartéis (idem, p. 228).

A partir de então, segundo Lemme (1988b, p. 229), o país foi tomado por "uma onda de reação, com milhares de prisões em todo o território nacional”. Em meio ao "ambiente pesado de denúncias, violências e sofrimento", os integralistas aproveitavam para "acusar todos os que não rezavam por sua cartilha verde de serem traidores da Pátria”. Mediante a afirmação de que o comunismo representava um perigo para o futuro do país e do povo, Vargas deu início a uma intensa perseguição e ameaça a todos os que defendiam ideias contrárias às iniciativas governamentais, inclusive aos que "lutavam para proporcionar maiores e melhores oportunidades de ensino, educação e cultura em benefício da maioria do povo brasileiro" (idem, p. 230).

Pressionado por setores da sociedade que o acusavam de esquerdismo, Anísio Teixeira pediu exoneração do cargo de Diretor da Instrução Pública do Distrito Federal. Segundo Pagni (2008, p. 26), desde 1931, quando assumiu o referido cargo, Anísio vinha sofrendo calúnias veiculadas pela intelectualidade católica, que o acusava de 
"ateu e comunista", devido à sua defesa de uma "escola laica, pública e gratuita" para promover a democracia, e a consequente desconsideração de preceitos religiosos na educação. Tais acusações atingiram maiores proporções em 1935, quando o Governo do Distrito Federal concedeu grande abertura ao "autoritarismo de seus opositores"; percebendo a impossibilidade de executar "seu projeto de democracia e sua aspiração à reforma da educação", Teixeira retirou-se da vida pública. Juntamente com outros colaboradores de Anísio, Lemme foi dispensado do cargo que exercia, voltando à função de professor nas escolas técnicas secundárias (idem, p. 35).

Pouco tempo depois, no início de 1936, o novo diretor, Roquete Pinto, por indicação de Venâncio Filho, convocou Paschoal Lemme (1988b, p. 240) para dirigir a seção de ensino para adultos, que nessa época abarcava o ensino primário. Apesar da remota possibilidade de êxito nessa nova tarefa, em decorrência do "ambiente cada vez mais confuso" e de sua proximidade com Anísio Teixeira, ele aceitou a nomeação de superintendente da Diretoria de Educação de Adultos e Difusão Cultural da Secretaria Geral de Educação e Cultura do Distrito Federal, por designação do ministro Francisco Campos (idem, p. 241).

A partir de então, a pedido do Prefeito Pedro Ernesto, começou a ministrar “cursos de alfabetização e extensão cultural” para operários (LEMME, 1988b, p. 252). Algum tempo depois, um jornal nazista declarou estranhar sua presença no cargo, lembrando que, durante a gestão de Anísio Teixeira, ele havia ministrado aulas para trabalhadores vinculados a uma associação operária denominada União Trabalhista (idem, p. 243). A denúncia ocasionou sua prisão, em 1936, sob a acusação de difundir orientações marxistas. Durante o ano e meio em que ficou detido, Lemme (idem, p. 275) fundou no presídio, juntamente com os colegas de cárcere, uma Universidade, sendo ele mesmo eleito reitor, tendo por finalidade "aproveitar os conhecimentos e talentos de muitos dos presos, alguns até de alta cultura, para ensinar e aprender tudo o que fosse possível".

Naquela ocasião, o autor teve contato com representantes da esquerda e com os líderes do Partido Comunista, fato que o levou à elaboração de novas concepções, bem como a perceber a relação intrínseca entre política e educação (BRANDÃO, 1999, p. 105). Lemme (1988b, p. 251) afirma que, nos interrogatórios a que foi submetido, jamais escondeu sua inclinação pelas "correntes socialistas, que pregavam e lutavam pela igualdade de oportunidades entre os homens, pela justiça social, por uma equitativa distribuição dos frutos do trabalho de todos". Quando questionado sobre o conteúdo de 
seus cursos, ele conta que respondia ter sido designado "em caráter oficial, por determinação do Prefeito", e que seu propósito era promover atividades de "alfabetização e extensão cultural, conforme previa o regulamento da Superintendência" por ele dirigida (idem, p. 252).

Absolvido do crime que supostamente havia cometido, Paschoal Lemme (1988b, p. 187) foi libertado em junho de 1937, sendo imediatamente reconduzido ao cargo de Inspetor Geral de Ensino, bem como ao de professor. Assim, conseguiu restabelecer sua "situação funcional e financeira, interrompida pela violência" ocasionada com sua prisão e com o "iníquo processo administrativo" a que todos os inspetores de ensino foram submetidos. Retornando à vida pública, Lemme "engajou-se definitiva e explicitamente na luta política" e passou a "reorientar as suas ações no sentido de trabalhar simultaneamente" nos terrenos da política e da educação, os quais "apareciam dissociados nas representações" da maioria dos educadores de sua geração (BRANDÃO, 1999, p. 105).

No mesmo ano, por meio de novo golpe desferido por Getúlio Vargas, teve início o Estado Novo, regime pautado na unidade de comando, tendo por justificativa a necessidade de livrar o Brasil da ameaça comunista (CUNHA, 1989, p. 30). Horta (1994, p. 149-150) explica que o projeto educacional posto então em prática visava instituir uma educação “de fundo acentuadamente nacional”, com a função de "elevar o nível cultural das elites dirigentes" e "melhorar a educação política da população em geral". O governo dizia que "extremistas" pretendiam conduzir nossa "obra educativa" segundo as suas ideologias, razão pela qual se fazia urgente que a escola preparasse o "homem completo", ou seja, "como pessoa, como cidadão e como trabalhador", e salvar o Brasil dos perigos que o ameaçavam (idem, p. 167).

A Constituição do novo regime vetou o acúmulo de cargos públicos, circunstância que obrigou Paschoal Lemme (1988b, p. 201) a optar por um dos cargos que havia recuperado, o de professor das escolas técnicas secundárias, "por ser o mais antigo e fazer jus a uma remuneração mais alta”, deixando, assim, a Inspetoria de Ensino. Em 1939, no entanto, ele ingressou, por meio de concurso, no Ministério da Educação, sendo alocado no Instituto Nacional de Estudos Pedagógicos, INEP, órgão criado dois anos antes com o objetivo de desenvolver estudos e inquérito educacionais, além de reunir e veicular documentação relativa ao ensino (CUNHA, 1989, p. 143). Lemme (1988b, p. 54) chefiou as seções de Documentação e Intercâmbios e de 
Inquéritos e Pesquisas até o final de 1942, quando, diante de divergências com Lourenço Filho, diretor do Instituto, preferiu afastar-se.

No ano seguinte, por indicação do amigo Francisco Venâncio Filho, foi designado para chefiar a Seção de Extensão Cultural do Museu Nacional, então dirigida por Heloísa Alberto Torres (LEMME, 1988b, p. 54). Concomitantemente, Lemme (idem, p. 56) passou a atuar no Instituto Nacional de Cinema Educativo, onde, com o apoio de outro amigo, Edgar Sussekind, organizou o "maior número possível de filmes e diafilmes que viessem atender às necessidades do ensino primário, secundário e superior", tornando-se, assim, um pioneiro do cinema educativo no Brasil.

Em 1945, com a proximidade da derrota "da reação e do fascismo", os defensores da renovação educacional começaram a retornar à vida pública (LEMME, 1988b, p. 168). O término do Estado Novo e a consequente volta do regime constitucional, em 1946, permitiram que Lemme recuperasse o direito ao cargo de Inspetor Geral de Ensino, mas, o que parecia ser o retorno à plena normalidade, não foi de fato, pois o cargo deixara de existir. Somente seis anos mais tarde, o governo do estado do Rio de Janeiro efetuou sua designação para novo cargo, o de professor de ensino normal, na cadeira de História e Filosofia da Educação. Lemme (idem, p. 202) atuou na formação de professores até 1961, quando obteve sua aposentadoria por tempo de serviço.

A partir de 1945, o autor voltou a atuar intensamente na $\mathrm{ABE}$, como membro do Conselho Diretor da entidade (LEMME, 1988b, p. 108). Na IX Conferência Nacional de Educação, realizada naquele ano, ele teve a oportunidade de contribuir na elaboração da Carta Brasileira de Educação Democrática, a qual exprimia seu posicionamento em defesa de "uma organização social em que a distribuição do poder econômico não estabeleça nem antagonismos nem privilégios”. Lemme (idem, p. 109) conta que teve importante participação também na X Conferência, ocorrida em 1950, na qual esteve presente como convidado e tomou parte em um levantamento de opiniões sobre as leis de diretrizes e bases da educação nacional, apresentando um documento intitulado "Estudos de Educação".

Em 1953, Lemme (2004a, p. 99) participou da I Conferência Mundial dos Educadores realizada em Viena, a convite da Federação Internacional de Ensino (FISE), organização filiada à Federação Mundial de Sindicatos, de tendência esquerdista. Naquela oportunidade, viajou também à União Soviética e à China, a fim de conhecer os sistemas educacionais desses países. Em 1957, o autor recebeu novo convite para 
participar da II Conferência Mundial dos Educadores, dessa vez realizada em Varsóvia, sendo designado relator da delegação brasileira.

O ano de sua aposentadoria foi também o ano da eleição de Jânio Quadros para a presidência da República, fato que Lemme (1988b, p. 209) descreve como "um lamentável equívoco de uma expressiva maioria do eleitorado brasileiro". Seu afastamento definitivo do serviço público, naquele momento, teve o propósito de "não compactuar com as situações" que considerava "de completa desorganização nos setores da administração pública em que atuava".

O início de 1964 trouxe ao Brasil uma nova realidade política e institucional, com a instauração de um regime militar de cerceamento das liberdades civis, o que motivou Lemme a escrever uma série de comentários críticos à situação educacional do país. Em 1975, ele decidiu enviar suas anotações, então transformadas em cartas, a dois jornais diários do Rio de Janeiro, O Jornal do Brasil e $O$ Globo, para serem divulgadas, se fossem "consideradas úteis e oportunas", o que realmente aconteceu e foi se ampliando, mediante novas contribuições do autor, até 1978 (LEMME, 1988c, p. 189).

Em 1982, Paschoal Lemme (1988c, p. 247) foi convidado a participar da II Conferência Brasileira de Educação, promovida em Belo Horizonte por diversas entidades, dentre as quais a Associação Nacional dos Docentes do Ensino Superior (ANDES), a Associação Nacional de Educação (ANDE), a Associação de PósGraduação e Pesquisa em Educação (ANPEd), o Centro de Estudos e Cultura Contemporânea (CEDEC) e o Centro de Estudos, Educação e Sociedade (CEDES). Lemme considerou o convite "a expressão de uma homenagem a um velho educador".

No evento, Lemme (1988c, p. 247) disse aos educadores presentes que aquele "momento difícil" exigia que todos dirigissem "suas preocupações fundamentais para os aspectos da educação e do ensino como problemas de caráter político-social" e não somente "como questões de natureza pedagógica, de didática, de metodologia ou de técnica de ensino". E complementou, afirmando que "um educador consciente de sua missão" tem a obrigação de "explicar e denunciar que o fracasso dessas crianças na escola, no ensino, é o resultado direto das condições subumanas em que vivem suas famílias" (idem, p. 258).

Lemme (1988c, p. 260) disse também que, depois de sessenta anos participando, "direta ou indiretamente, de tudo o que neste país se tentou realizar de mais significativo e progressista em matéria de educação e ensino", aquela era a primeira vez que podia verificar o quanto os educadores brasileiros estavam adquirindo 
"consciência" de uma "verdade elementar - somente numa sociedade democraticamente organizada" pode haver "o florescimento de uma educação de caráter democrático", isto é, “aquela que é posta a serviço de todo o povo e tem como pressuposto, ainda que em caráter de ideal a ser conquistado palmo a palmo por uma luta sem tréguas, a igualdade de oportunidades para todos".

Foi nessa mesma época que o autor passou a escrever suas memórias, cujos três primeiros volumes foram publicados em 1988 pela Editora Cortez em associação com o INEP, em razão das comemorações dos 50 anos desse órgão federal (BRANDÃO, 2002a, p. 886). Em seguida, passou a organizar diversos documentos de sua autoria, bem como uma série de cartas que havia trocado com os líderes do movimento escolanovista, iniciativa que deu origem aos volumes quarto e quinto de suas memórias, os quais foram publicados em 1991 e 2004, respectivamente, pela mesma editora.

Lemme (1988b, p. 10) confessa que a iniciativa de organizar suas memórias foi inspirada no fato de ter participado, "mesmo modestamente, de alguns acontecimentos importantes, especialmente no que se refere à história da educação e do ensino no País", razão pela qual considerava legítimo registrar seu "depoimento" sobre as "figuras mais significativas que desencadearam ou impulsionaram o processo de modernização da educação e do ensino no Brasil", a fim de que, "no futuro, talvez" pudesse "servir de base ou inspiração para trabalhos de maior valia”.

A partir de então, Lemme recebeu várias homenagens, premiações e honrarias, como o título de Doutor Honoris Causa, em 1995, concedido pela Universidade Federal Fluminense, e de Professor Emérito, pela Universidade do Estado do Rio de Janeiro, em 1996. Todas as honrarias prestadas a ele serviram para expressar "o reconhecimento das gerações mais novas de educadores do papel muito peculiar deste Pioneiro da Escola Nova no cenário da educação brasileira" (BRANDÃO, 2002a, p. 879). Paschoal Lemme faleceu no dia 14 de janeiro de 1997, aos 92 anos de idade. 


\section{III - O LOGOS DO ORADOR}

A narrativa de fatos pretéritos feita com o olhar do presente contribui para construir certa imagem de quem foi e de quem é o autor, das circunstâncias e dos conflitos que o conduziram ao lugar em que se encontrava no momento em que o relato se desenvolveu - o que, nos termos da análise retórica, denominamos ethos do orador, objeto do segundo capítulo deste trabalho. O recurso à narrativa memorialística contribui também para construir disposições favoráveis ao conteúdo do discurso proferido - conjunto de argumentos que a análise retórica denomina logos.

A autobiografia, portanto, veicula argumentações que se prestam a conferir credibilidade não só ao autor, mas principalmente à tese por ele defendida, com o intuito de angariar a adesão da audiência. Muitos dos fatos descritos por Paschoal Lemme em suas memórias, apresentados no capítulo precedente, vêm acompanhados de apreciações feitas pelo autor, o que permite compreender as teses por ele defendidas ao longo de sua carreira profissional. ${ }^{8}$

Lemme sempre atuou na vida pública em órgãos estatais e em estreita colaboração com os líderes do movimento escolanovista, manifestando, porém, certa discordância quanto ao ideário por eles defendido. Mais precisamente, uma discordância fundamental: Lemme declara-se comunista, adepto das formulações marxistas, defendendo a tese de que a educação brasileira só será verdadeiramente renovada após a transformação política e econômica do país.

\section{Convergências e divergências do missionário}

No decorrer dos cinco volumes de suas memórias, Paschoal Lemme menciona vários episódios em que teve a oportunidade de expor seus posicionamentos perante a situação educacional brasileira, destacando que as suas teses não coincidiam com as que eram defendidas pela maioria dos educadores escolanovistas. Dentre os renovadores com quem atuou no serviço público, o autor não faz nenhuma ressalva a Fernando de Azevedo, responsável pela reforma do ensino no Distrito Federal no final da década de 1920; ao contrário, tece considerações muito favoráveis às iniciativas daquela gestão, como foi registrado no segundo capítulo deste trabalho.

\footnotetext{
${ }^{8}$ Os episódios da vida profissional de Lemme examinados neste capítulo foram contextualizados no capítulo precedente, razão pela qual não serão novamente descritos.
} 
O mesmo não pode ser dito quanto a Anísio Teixeira, de quem Lemme foi íntimo colaborador durante a reforma do ensino instituída no início dos anos de 1930, também no Distrito Federal. É certo que os dois educadores nutriam sentimentos de admiração e amizade recíprocos, como afirma o próprio Lemme (1988b, p. 134), mas isso não o impede de comentar criticamente que Anísio exibia certos "traços americanos" em sua atuação, e que as suas medidas reformistas exibiam "possíveis 'pecados' da 'americanização"”.

Brandão (1999, p. 107) analisa esses comentários considerando que Teixeira era orientado pelo espírito do "reajustamento democrático", tendo como situação exemplar os Estados Unidos da América. Seu ideário alimentava a crença de que a educação era o único instrumento capaz de produzir uma nova sociedade e uma "política sã". Adotando a renovação educacional como caminho para alcançar uma "sociedade verdadeiramente democrática", seria possível superar o atraso do Brasil em relação ao mundo desenvolvido, uma vez que, por intermédio de uma nova escola, o povo seria preparado para a democracia (idem, p. 86).

A contrariedade frente a esses ideais talvez espelhe certa discordância com as concepções de John Dewey, pois, segundo Brandão (1999, p. 86), Lemme tinha conhecimento da influência exercida por teóricos americanos sobre Teixeira, cuja defesa de um "modelo de educação para a democracia" seria advinda da filosofia deweyana. Lemme não desenvolve análises com tal abrangência, mas, ainda segundo Brandão (idem, p. 81), seu relato evidencia claro distanciamento em relação à crença de Anísio no poder da educação para gerar o desenvolvimento social, pois não acreditava que a "equalização das oportunidades sociais" poderia resultar da "democratização do acesso à escola". Para ele, Teixeira era portador de uma "visão ingênua" acerca da realidade dos pobres, por imaginar que bastava ensinar a ler e escrever para solucionar a condição desumana de vida daquela classe social, exprimindo assim um "preconceito muito comum sobretudo entre as camadas médias da sociedade - em relação à pobreza" (idem, p. 88-89).

Na época em que colaborou com Anísio Teixeira, Lemme (1988b, p. 213) teve seu interesse voltado para a filosofia, mais precisamente para as teses do marxismo, o que ocorreu por intermédio do seu amigo Valério Konder, médico sanitarista e militante do Partido Comunista, com quem atuou a partir de 1933 na Inspetoria de Ensino, e Alberto Carneiro Leão, professor da cadeira de inglês das escolas técnicas-secundárias, 
que foi seu colega no curso noturno da Escola de Comércio Amaro Cavalcanti durante a administração de Azevedo no Distrito Federal.

Lemme (1988b, p. 217) relembra que nesse período sofria também a influência de dois de seus irmãos, Antônio Lemme Júnior, formado em Odontologia, que possuía "posição de relevo na direção do Partido Comunista”, e Humberto Lemme, Agrônomo, que atuava na secretaria da Aliança Nacional Libertadora. Por intermédio de Humberto, Paschoal Lemme (idem, p. 217) aderiu formalmente à ANL, mas afirma nunca ter participado em suas manifestações, nem frequentado sua sede, pois além da "falta de tempo" por causa das "responsabilidades de família" e profissionais, nunca se envolveu em qualquer agremiação partidária.

Sua narrativa dos fatos que sucederam dali por diante é marcada por considerações pautadas no ideário e nas práticas comunistas, aos quais afirma ter aderido, embora com algumas reservas, pois, como afirma Brandão (1999, p. 104), o autor nunca se inscreveu nos quadros do Partido Comunista Brasileiro, PCB. Lemme (1988b, p. 227-228) manifesta uma visão crítica ao PCB, considerando, por exemplo, que a atuação de seus militantes foi responsável pelas perseguições desencadeadas por Getúlio Vargas em 1935 após a Intentona, motivando o golpe de estado desferido dois anos depois. Para Lemme, a agremiação comunista brasileira apresentava "séria distorção" devido ao "predomínio de uma corrente militar, que, por sua própria formação ou deformação profissional, tendia sempre a resolver os problemas políticos pela ação armada". Segundo avalia, os comunistas mantinham uma organização de caráter "secreto e misterioso", nada condizente com os princípios que ele defendia - a “discussão livre" e a "liberdade de pensamento e ação" (idem, p. 214).

Para Brandão (2002a, p. 883), a "situação de intelectual de esquerda, fora dos quadros do Partido Comunista, e de educador renovador 'convertido' ao marxismo deixou Lemme numa posição de relativo isolamento", fato que "dificultou o aprofundamento da reflexão marxista entre os educadores de sua geração". Lemme somente colaborou com o Partido Comunista no período da legalidade dessa agremiação, a partir de 1945, quando passou a escrever nos jornais Imprensa Popular, Tribuna Popular e Classe operária, pertencentes ao Partido; após 1947, também colaborou, atuando na área de educação, com a Fração Parlamentar, organização de esquerda que assessorava as bancadas do PCB na Câmara Federal e na Assembleia Legislativa do Distrito Federal (BRANDÃO, 1999, p. 202). 
Embora discordando de Anísio Teixeira, Lemme o acompanhou até o final de sua Administração, em 1935, a qual foi encerrada devido à grande desconfiança alimentada contra aquele educador, conforme já foi descrito neste trabalho. Sua atitude foi diferente em relação a outro importante líder escolanovista, Lourenço Filho, com quem trabalhou no INEP e de quem também divergiu. Lemme não esclarece as razões de sua contrariedade, e os trabalhos que versam sobre o assunto são pouco esclarecedores (ver BRANDÃO, 1999; BRANDÃO, 2002b; BRANDÃO, 2003). Brandão (2002b, p. 47) registra, apenas, que Lemme preferiu afastar-se do cargo que então ocupava por não aceitar a "orientação imprimida à Política de Educação por Lourenço Filho" e, particularmente, por causa do apoio do diretor do INEP às “orientações do Estado Novo".

Não se pode afirmar que a adesão de Lemme ao pensamento marxista tenha sido responsável por suas discordâncias com Lourenço Filho, mas é certo que a sua proximidade com essa corrente filosófica já era notória em meados da década de 1930, antes mesmo de seu ingresso no INEP. Ao analisar os manifestos elaborados naquela época por Lemme em coautoria com Valério Konder - intitulados "A Reconstrução Educacional no Estado do Rio de Janeiro" e "Os Inspetores de Ensino do Estado do Rio de Janeiro ao Magistério e à Sociedade Fluminense" -, Brandão (1999, p. 75) considera que a linguagem adotada pelos autores deixava evidente a sua adesão ao marxismo. Seu posicionamento era claramente favorável à tese de que "reformas educacionais" visando à "democratização da escola" só se concretizariam mediante mudanças na "distribuição da riqueza" gerada pelo "trabalho livre"; quando tais reformas "não são articuladas a mudanças sociais mais profundas", terminam sendo impostas "de cima para baixo", o que explica, em parte, o seu insucesso.

Mesmo discordando do pensamento predominante entre os escolanovistas, Lemme permaneceu ligado à luta por eles sustentada em prol da renovação educacional. Em vários outros momentos de sua trajetória, ele conseguiu exprimir suas ideias concernentes à natureza da relação entre escola e sociedade, as quais, em suma, sustentam que as mudanças sociais devem anteceder as mudanças educacionais. Mesmo nos momentos difíceis que marcaram os anos de 1935 a 1945, Lemme afirma nunca ter hesitado em expor suas ideias e lutar pela missão que havia assumido como educador e intelectual: fazer do Brasil um país verdadeiramente democrático.

Segundo o autor, durante toda a sua vida, nos locais e instituições onde exerceu atividades, seus posicionamentos foram "sempre defendidos sem a preocupação de 
agradar ou desagradar quem quer que fosse". Exemplo disso foi seu retorno à Associação Brasileira de Educação após a prisão, ocasião em que, muitas vezes, ficou "praticamente sozinho contra toda a totalidade" de seus "companheiros", mas, mesmo assim, não deixou de defender suas ideias e lutar pelo que acreditava (LEMME, 1988b, p. 209).

Brandão (1999, p. 109-110) afirma que, depois de 1937, Lemme tornou-se "uma voz dissonante na ABE"; suas teses esquerdistas e sua proximidade com líderes comunistas durante a prisão incomodavam "os ouvidos acostumados à valorização da educação como instrumento privilegiado das transformações sociais”. Mesmo sendo considerado membro do grupo dos pioneiros, ele foi se tornando "solitário, 'estrangeiro' mesmo, entre os educadores liberais". Apesar disso, permaneceu na ABE, defendendo continuamente suas concepções até o ano de 1963, momento em que a sua reeleição para o Conselho Diretor da entidade foi considerada "inconveniente", segundo as suas próprias palavras (LEMME, 1988b, p. 110).

O término do Estado Novo possibilitou que ele manifestasse com mais liberdade e clareza as concepções filosóficas que defendia, em oposição a muitos de seus pares. Na IX Conferência Nacional de Educação, em 1945, na qual contribuiu para a confecção da Carta Brasileira de Educação Democrática, Lemme (1988b, p. 108) defendeu a tese de que as mudanças na educação devem ter por base "uma organização social em que a distribuição do poder econômico não estabeleça nem antagonismos nem privilégios". Na Conferência seguinte, realizada em 1950, quando apresentou o documento "Estudos de Educação", ele questionou o norteamento adotado por membros da $\mathrm{ABE}$, os quais, segundo ele, manifestavam "exagerado 'otimismo pedagógico", acreditando nas reformas da educação como meios para conduzir o Brasil ao progresso (idem, p. 109).

Nessa mesma Conferência, apesar da contrariedade da maioria dos presentes, Lemme (1988b, p. 109), “já com bastante nitidez” acerca de sua "nova posição perante” os "graves problemas da nacionalidade", defendeu que "reformas de educação e ensino não transformam a sociedade"; ao contrário, são "as transformações sociais, que impulsionadas por fatores básicos internos à própria sociedade, é que passam a exigir mudanças", de modo a "atender as novas condições criadas". Por isso, disse ele ainda, é essencial que exista uma "educação política" que busque "revelar ao indivíduo a verdade sobre todo o contexto em que vive e sua posição nele", para que essa "verdade exerça todo o poder mobilizador" que somente ela possui (LEMME, 1988c, p. 73-74). 
Sempre enfrentando oposição às suas convicções, Paschoal Lemme (1988c, p. 88-89) buscou mostrar a seus colegas renovadores que em países como o Brasil é papel dos "intelectuais" ajudar o povo brasileiro na "luta fundamental contra o subdesenvolvimento", fator que gera o latifúndio e o imperialismo, e permite a existência de trustes e monopólios que oprimem a população. Segundo os seus princípios, essa é a "obra de educação e esclarecimento que o povo brasileiro exige de seus professores e educadores e não planos utópicos de 'erradicação' do analfabetismo em prazo certo", tentativa que apenas resulta em "dispêndio de bilhões, numa campanha demagógica e improdutiva que a nada conduzirá de efetivo". Para o autor, somente a "completa libertação nacional" fará com que a educação e o ensino deixem de ser "privilégio de minorias" para se tornarem realmente elementos formativos, em vez de apenas conferir "graduação social", como ocorreu durante toda a história da educação brasileira (idem, p. 104).

Como se pode notar pelo teor dessas intervenções, Lemme parece ter tido, na Conferência de 1950, a primeira chance real de confrontar os líderes escolanovistas que vinha seguindo desde os anos de 1920 e dos quais discordava desde a década de 1930, quando se aproximou do marxismo. O confronto se deu pela afirmação, feita por Lemme, da relação intrínseca entre política e educação na luta por um país verdadeiramente democrático; pela sustentação de que a adoção de medidas técnicas, isoladamente, não poderia jamais alcançar essa meta. Ao defender tais ideias naquela ocasião, sua narrativa revela, mais uma vez, a imagem de um homem absorvido por uma missão, destemido e capaz de enfrentar não só os opositores evidentes - como foi o Estado Novo, por exemplo -, mas também aqueles que eram por ele tratados como companheiros de caminhada em prol da renovação educacional.

Para compreender a permanência de Paschoal Lemme por tanto tempo ao lado de homens de quem discordava, podemos recorrer a Brandão (2002a, p. 881), cujas análises indicam dois dados significativos. O primeiro diz respeito ao posicionamento assumido pelos escolanovistas quanto à valorização do setor público em questões educacionais, negando, portanto, os interesses privados da oligarquia brasileira e promovendo, assim, uma verdadeira “desprivatização do setor público". Lemme considerava esse posicionamento verdadeiramente progressista. O segundo dado examinado por Brandão (1999, p. 112) sugere que o autor teria aceitado a liderança dos escolanovistas devido a seu caráter de ativista. Ele acreditava ser inútil ficar parado à espera das mudanças sociais que tanto almejava, mas tinha consciência de que seria 
impossível travar combate contra a maioria, pois isto despertaria em seus pares aversão imediata pelas ideias que defendia.

Ao mesmo tempo, também, ele sentia necessidade de agir, e para isso, o mais sensato era permanecer associado aos escolanovistas, podendo assim continuar no interior das repartições públicas e lutar, naquele ambiente, por melhores condições de educação para o povo. Acreditava que, procedendo desse modo, poderia mostrar aos líderes do movimento renovador e ao povo em geral o quanto era imprescindível desencadear uma luta mais ampla, não restrita ao campo educacional, mas que abrangesse a base econômica, política e social do país, para que verdadeiras transformações acontecessem (BRANDÃO, 1999, p. 112).

Ainda seguindo Brandão (1999, p. 112), pode-se interpretar a permanência de Lemme sob o comando dos escolanovistas como uma estratégia posta em prática com o objetivo de criar uma nova intelligentsia educacional, uma "intelligentsia de esquerda entre os educadores de sua geração" que priorizasse a união de temáticas políticas e educacionais no processo de reorganização da educação brasileira - concepção por ele adotada durante sua prisão, mediante a influência comunista, como mencionado no capítulo anterior. Permanecendo entre os renovadores, Lemme procurou "desenvolver um intenso trabalho no sentido de convencer seus pares sobre a necessidade de articular o trabalho profissional e a militância política"; para ele, tal militância tornou-se "indispensável” para a existência de uma "ação continuada de transformação social e educacional" (idem, p. 105).

As análises de Brandão (2003, p. 73) sugerem que Lemme buscava mostrar aos professores e a todos os brasileiros que a luta pela educação possuía caráter político, sendo necessário, portanto, ir além da mentalidade vigente entre os educadores de sua geração, toda ela pautada em uma forma de representação "relativamente apolítica", fundamentada na vã esperança de "organizar a educação da futura nação sem vínculos político-partidários". Esse modo de pensar levava à "marginalização" dos problemas educacionais perante as "decisões maiores a respeito da sociedade", ocasionando o sucesso das políticas que pretendiam manter a educação "submissa, disciplinada e controlada", nos limites do modelo conhecido como "modernização pelo alto" (BRANDÃO, 1999, p. 138).

Com o objetivo de criar uma nova intelligentsia educacional, ao retornar à vida pública em 1937, Lemme procurou se aproximar de partidos e outras formas de agremiação, buscando mobilizar e articular os setores que considerava serem os "mais 
prejudicados pela estrutura social injusta". Sua atuação tinha por meta organizar tais setores para que conseguissem encaminhar de maneira consistente as suas reivindicações. Para atingir seu objetivo, o autor também assumiu um posicionamento contrário à "má-política" adotada por aqueles que seguiam "os interesses de uma minoria, fruto da imposição das elites dirigentes tradicionais" (BRANDÃO, 2003, p. 73).

Para Brandão (1999, p. 110), Lemme "nunca deixou de se sentir um dos pioneiros da educação"; ele sempre reafirmava o "orgulho" que sentia por pertencer ao grupo responsável por formular "os princípios e diretrizes de um Sistema de Ensino 'de massas', no sentido de ser aberto a todos os cidadãos" (BRANDÃO, 2002b, p. 45). Porém, uma das características marcantes de sua personalidade, compartilhada com a geração do começo do século passado, era a "independência político-ideológica". Mesmo sendo "colaborador e simpatizante" do Partido Comunista, Lemme sempre "rejeitou submeter-se à rígida disciplina partidária que limitava a autonomia de pensamento de seus quadros"; sua trajetória é o exemplo de uma "estratégia" que visava "articular os setores progressistas de dois campos distintos - profissional e político", tendo em vista a "luta pela democratização da sociedade" (BRANDÃO, 1999, p. 109110).

Brandão (1999, p. 110) afirma ainda que a "opção político-ideológica" de Lemme era muito diferente da adotada pelos educadores liberais, sendo norteada por conceitos como "classes sociais e sociedade" e não por noções como "indivíduo e nação". Enquanto os liberais "pensavam a democratização da sociedade e da educação como um amplo processo de mobilidade social baseado nas características individuais", Lemme, fundamentado na filosofia marxista, abordava as mesmas questões por intermédio da "luta de classes". Para ele, não se consideram as características individuais em uma sociedade dividida em classes, uma vez que as "contradições que se estabelecem entre os homens" que as integram "fazem com que uns lutem pela permanência da situação que lhes é favorável, enquanto que outros procuram transformar a ordem reinante" que os "oprime e prejudica" (LEMME, 1988c, p. 159). Brandão (1999, p. 110) analisa que as ideias de Lemme acerca das relações entre as esferas social e educacional encontravam "decisivo apoio" somente no âmbito do Partido Comunista.

Em um de seus contatos com Lemme, em função da tese de doutorado que escrevia, Brandão (1999) questionou sobre como foi possível manter tal "independência 
político-ideológica" em uma trajetória tão longa, iniciada na década de 1930. Em carta datada de 23/04/1991, o autor respondeu:

(...) consegui, com toda a naturalidade, mas também com a estranheza de muita gente, estabelecer relações cordiais com as mais variadas correntes de pensamento, aprendendo com elas o que podia e devia ser aprendido, reavaliando permanentemente minhas ideias, posições e atividades, sempre mantendo, porém, a minha independência de pensamente e de expressão (LEMME, 1991, apud BRANDÃO, 1999, p. 111).

Como explica Vanilda Paiva (2004, p. 17) no prefácio do quarto volume da obra Memórias, Lemme merece especial atenção entre os educadores daquela época por ter sido "o primeiro a assumir uma posição intelectual nitidamente de esquerda e a trabalhar diretamente com as forças políticas"; ele foi o "precursor de uma corrente de análise da educação que não se confunde com aquela representada por Anísio Teixeira, Fernando de Azevedo e outros nomes destacados do movimento renovador"; sua constante defesa de posicionamentos próximos aos do Partido Comunista Brasileiro, mesmo sem ter tido militância como filiado, rendeu-lhe o título de "intelectual de esquerda", um "precursor da intelectualidade independente - algo que se tornou moda no início dos anos 80, mas que certamente constituía uma raridade das décadas pretéritas".

\section{O marxismo do missionário}

A autobiografia de Lemme e os documentos reunidos nos volumes finais de suas memórias permitem assim resumir os posicionamentos por ele assumidos no decorrer de sua vida: o autor faz severa crítica aos educadores brasileiros que analisam os problemas educacionais "em termos simplesmente "escolares", fazendo da escola o "instrumento principal das transformações econômicas e sociais" que o país requer; diferentemente desse ponto de vista, o autor afirma que a renovação do ensino não é capaz de determinar alterações na vida nacional, pois somente a transformação radical das bases econômicas e sociais pode levar às almejadas mudanças educacionais (LEMME, 2004a, p. 40).

Para irmos além dessa formulação geral e nos aproximarmos, o máximo possível, do núcleo do pensamento de Lemme, deveremos tentar compreender a visão marxista por ele adotada já no início da década de 1930, quando foi apresentado a essa 
filosofia. É preciso notar, no entanto, que o autor pouco esclarece a esse respeito, o que nos impele a recorrer a interpretações alheias e, também, a fazermos as nossas próprias ilações, tomando cuidado para não nos distanciarmos do que se encontra escrito na narrativa autobiográfica de Lemme e nos textos de sua autoria.

O primeiro registro das concepções filosóficas do autor aparece nos manifestos elaborados por ele em coautoria com Valério Konder em meados da década de 1930, os quais, conforme mencionado no segundo capítulo deste trabalho, conclamavam à sociedade fluminense e o magistério a tarefa de empreender a reconstrução educacional e social. Sua tese de que a democratização da escola seria uma decorrência da distribuição dos bens gerados pelo trabalho leva Brandão $(1999$, p. 91) a dizer que tais textos expressam uma concepção marxista, uma vez que têm por base a ideia de que a educação constitui um "fenômeno de superestrutura", não possuindo, portanto, "autonomia" sobre as problemáticas sociais, como se encontra no Manifesto dos Pioneiros da Educação Nova; por esse motivo, a renovação do ensino não pode ser vista como o "motor" das transformações na sociedade. Ao contrário dos educadores liberais, Lemme pensava a educação como dependente da esfera política, social e econômica, a qual, segundo a filosofia marxista, contém "fenômenos de estrutura"; seguindo este raciocínio, a base estrutural influi na superestrutural, sendo esta um reflexo daquela, e não o inverso.

A visita à União Soviética em 1953 parece ter exercido poderosa influência na concepção política de Lemme e na confirmação de seus ideais educacionais, pois, em suas memórias, ele defende enfaticamente aquele país, dizendo que muitas críticas infundadas são feitas por faltar aos brasileiros o conhecimento correto acerca do que realmente acontece lá. Lemme (2004b, p. 163-164) afirma a sua plena adesão ao "marxismo-leninismo", ou "materialismo dialético e materialismo histórico", filosofia que considera a "verdadeira interpretação do universo", bem como "do homem e de sua vida em sociedade", e conclui que a tese de que a transformação social é o condutor da renovação educacional guiada por preceitos democráticos, por ele sempre defendida, tem por lastro o que presenciou na URSS.

Ao que parece, a União Soviética é vista pelo autor como regida por princípios democráticos, e o marxismo, como uma filosofia que prega esses mesmos princípios, razão pela qual ele defende o aprofundamento da democracia como solução para os problemas brasileiros. Segundo Lemme (2004b, p. 73), a democracia é o regime mais adequado para obter a reconfiguração da vida econômica, assim como as mudanças 
verdadeiramente necessárias à renovação educacional, pois "somente sob um regime democrático pode ser empreendida a educação do povo"; é "falsidade evidente toda a doutrina educacional ou política que pretende formar bons cidadãos num ambiente onde foi anulado o exercício dos deveres cívicos elementares", como o "de escolher os representantes da Nação", e o exercício de "discutir e fiscalizar os atos dos detentores do poder".

Lemme (2004a, p. 133) defende que em países em desenvolvimento, como era então considerado o Brasil, é essencial que haja uma transformação econômica radical; só assim tais países poderão conquistar autonomia perante as nações imperialistas, pois "somente uma economia independente" permitirá que "governos democráticos" aumentem "substancialmente os orçamentos para a educação e a cultura", possibilitando, assim, “construir e equipar convenientemente as escolas necessárias", o que, por sua vez, proporcionará aos educadores "as condições de trabalho e os níveis de salários compatíveis com a dignidade de sua missão".

No entanto, a garantia efetiva do direito à educação não se faz somente por meio de "escolas em número suficiente e devidamente aparelhadas", uma vez que o estudante precisa ter à sua disposição as condições adequadas para chegar à instituição de ensino; a criança necessita ter "boas condições físicas e mentais" e permanecer na escola "pelo tempo considerado necessário para obter, em cada caso, o desejado aproveitamento no ensino" (LEMME, 2004a, p. 157). Para que tudo isso aconteça, é essencial que haja uma "sociedade organizada democraticamente", que entenda que "educação e ensino são direitos e necessidades fundamentais do homem e do cidadão, de acordo com o princípio básico da igualdade de oportunidades para todos" (idem, p. 157).

O corolário dessa reflexão é a seguinte tese, frequentemente afirmada por Lemme (2004a, p. 157): dizer que a educação e o ensino são "direitos e necessidades fundamentais de todas as pessoas humanas" é reconhecer a prioridade dos "problemas político-sociais" sobre as "questões apenas de caráter pedagógico, de didática ou de técnica de ensino". Solucionar os referidos problemas, segundo o autor implica defender a ideia que um "homem novo" só aflora no interior de uma "nova sociedade que se afirma, dia a dia, em marcha para uma sociedade futura", a qual se caracteriza pela “divisão racional do trabalho e, em consequência, pela mais estrita interdependência entre os homens" (idem, p. 242). Esse processo resulta "necessariamente em maior coesão, maior solidariedade entre esses homens", possibilitando "que todos, extintas as 
castas e classes que hoje os dividem e se combatem entre si, tenham oportunidade igual para se afirmarem como valores sociais".

No horizonte desse raciocínio, portanto, encontra-se a sociedade sem classes, tal qual afirmado pela teoria marxista. É para alcançar essa meta que Lemme (2004b, p. 151) indica a luta pela democracia, afirmando que "o problema fundamental do Brasil é a democratização da sociedade", e que "lutar por esse objetivo é, portanto, a obrigação maior de todos os brasileiros, principalmente daqueles que, por suas próprias atividades, devem possuir uma consciência mais clara dessa questão", que são "os chamados intelectuais, de modo geral, e, particularmente, os professores e educadores", cuja responsabilidade consiste em "preparar as novas gerações". 


\section{IV - A RETÓRICA DO ORADOR}

O segundo capítulo do presente trabalho focalizou a construção do ethos do orador, representado pela narrativa em que Paschoal Lemme apresenta a si mesmo como um homem predestinado a operar no campo da educação, atuando em prol de transformar a realidade. Sua autoimagem foi então qualificada como a de um missionário conduzido por um inabalável ideal de sociedade.

O capítulo seguinte mostrou que o $\operatorname{logos}$ do orador, na apreciação dos acontecimentos por ele vividos, põe em destaque as suas teses políticas e educacionais, as descrevendo como conflitantes com os posicionamentos dos demais escolanovistas. Mesmo sem a compreensão - muitas vezes com a rejeição - de seus contemporâneos, a trajetória de Lemme é por ele descrita como vitoriosa, o que se evidencia pelo fato de a comunidade acadêmica ter enaltecido os seus feitos, ainda que tardiamente.

Seguindo os norteamentos apresentados no primeiro capítulo deste trabalho, é possível examinar o discurso memorialístico do orador Paschoal Lemme por intermédio da análise retórica, buscando em seus relatos acerca de si mesmo e em suas apreciações dos fatos por ele vividos as estratégias argumentativas potencialmente capazes de mobilizar seus leitores, a audiência composta por profissionais da educação que atuavam na década de 1980, quando as Memórias foram publicadas.

\section{A cena teatral, o herói e as paixões da audiência}

Em sua narrativa autobiográfica, Paschoal Lemme descreve a si mesmo como possuidor de uma inclinação quase inata, descoberta ainda na infância, para lidar com temáticas educacionais; incansável diante dos obstáculos lhe impostos, o autor demonstra grande disposição de seguir a carreira de professor, dotado de inesgotável energia para lutar pela renovação do ensino e pela transformação do país. No transcorrer de seu discurso, as suas condutas e a sua visão do mundo ganham credibilidade perante a sua audiência, os leitores de suas memórias.

Lemme surge das páginas de sua autobiografia como um homem imbuído de uma missão, uma vocação da qual não pode escapar, o que constrói uma autoimagem messiânica. No desenvolvimento de seu discurso, essa autoimagem positiva é associada à defesa de determinadas ideias, as quais se beneficiam sobremaneira por serem abraçadas por alguém dotado de qualidades excepcionais. Nota-se, aqui, o uso da estratégia argumentativa que consiste em transferir as qualidades de uma pessoa aos 
atos por ela praticados ou às teses por ela defendidas (PERELMAN; OLBRECHTSTYTECA, 2005, p. 341). A construção de uma autoimagem messiânica permite que Lemme angarie prestígio perante sua audiência, sendo visto como um indivíduo singular, portador de concepções a serem seguidas (idem, p. 345).

Essa forma de articulação discursiva permite que as atitudes do orador assumam o caráter de superioridade perante os demais indivíduos, fazendo com que as suas atitudes sejam vistas como necessárias (PERELMAN; OLBRECHTS-TYTECA, 2005, p. 345). Os posicionamentos de Lemme ante os problemas sociais e educacionais ganham a aparência de imprescindíveis à modernização do país. O obstinado “intelectual de esquerda", como diz Paiva (2004, p. 17), que luta incansavelmente para defender seu ideário fundamentado em preceitos marxistas torna-se, aos olhos de seus leitores, um intelectual destacado dos demais, o que lhe garante respeito, prestígio que se estende às concepções por ele defendidas.

A descrição feita por Lemme dos acontecimentos de sua vida pessoal e profissional, como a descoberta precoce de sua vocação, o fortalecimento de sua missão e a sua escolha pelo marxismo, combatendo dentro de um ambiente dominado por liberais, faz dele uma figura de pensamento diferenciado, um "precursor da intelectualidade independente", que assume solitariamente a luta contra os ditames de um "país politicamente truculento e primário", segundo as palavras de Paiva (2004, p. 17). Paschoal Lemme atribui a si mesmo papel privilegiado no interior de um drama que ele mesmo desenha, o drama do Brasil nas primeiras décadas do século XX, erguendose à posição de um personagem quase mítico.

$\mathrm{Na}$ narrativa das dificuldades que Lemme encontrou para realizar sua missão, nota-se o emprego do que Perelman e Olbrechts-Tyteca (2005, p. 282) denominam "argumentação pelo sacrifício", estratégia discursiva em que o orador assume o papel do mártir que oferece sua vida em prol de um ideal, uma fé professada de maneira inquestionável, dogmática. O valor daquilo por que se opera o sacrifício é medido pela intensidade do próprio sacrifício. Assim, os ideais de Paschoal Lemme assumem grandeza ímpar por serem defendidos por um homem que se submeteu a atuar sob o comando de líderes de quem discordava e que sofreu injustiças - sendo preso, inclusive - em nome de suas crenças.

Nessa narrativa composta pela exposição de atributos pessoais, dificuldades sofridas e sucessos alcançados, nota-se o uso do que Billig (2008, p. 56) denomina "metáfora teatral", recurso discursivo em que o orador descreve os acontecimentos de 
sua própria vida como se fizessem parte de uma peça de teatro; peça escrita por ele mesmo com o intuito de posicionar os seus atos no centro no enredo. Nessa forma de expressão artística, em que cada ator assume determinado papel em determinado contexto perante o público, são encenadas situações conflitantes seguidas de condutas a serem tomadas como referência positiva para os espectadores. Ao colocar a si mesmo como protagonista de um drama, o drama vivido pelo país, em especial no campo da educação, Lemme transforma as suas teses em exemplo para aqueles que o leem.

Para ser efetivamente persuasivo, o recurso argumentativo da cena teatral deve ser moldado segundo algumas características fundamentais. Billig (2008, p. 61-62) considera que uma dessas características é a forma de exposição dos acontecimentos em que o narrador tomou parte. Discursos que descrevem trajetórias de maneira ordenada, sequencialmente, têm por objetivo enfatizar o sentido de continuidade e difundir a ideia de unidade, uma vez que a fragmentação é socialmente considerada indício de desordem, quando não de fraca articulação psicológica. Deve-se evitar que a trajetória de vida soe confusa, sem sentido; os fatos devem ser cronologicamente dispostos para que sua exposição resulte uma imagem positiva do orador perante a audiência.

Pode-se notar essa característica na autobiografia de Lemme, que é composta por volumes temáticos abrangendo sua vida pessoal, sua trajetória profissional e reflexões sobre documentos e escritos de sua autoria, percorrendo cinco décadas; cada volume é dividido em capítulos que exibem ao leitor, ponto a ponto, a ascensão do autor em busca de cumprir sua missão, compasso em que se elabora, pouco a pouco, a imagem de um homem obstinado e persistente. A figura do herói mítico vai sendo forjada em episódios permeados por problemas, dentro de uma cena adversa à concretização de seus ideais messiânicos; apesar do contexto adverso, o protagonista não esmorece, pois as suas qualidades e habilidades superam todos os entraves.

A figura de Paschoal Lemme aflora como a de um herói incompreendido em sua época, mas plenamente aceito pela posteridade, uma vez que os seus princípios morais nunca visaram ao benefício pessoal; sua meta sempre consistiu em favorecer o progresso do país, pensando particularmente em seu povo, privilegiando as camadas sociais que historicamente foram impedidas de ter acesso aos bens materiais e culturais. Lemme deseja modernizar o Brasil, o que, para ele, significa instituir um regime de vida democrático; e não se trata de uma visão social qualquer, pois uma situação real é oferecida pelo orador como modelo - a União Soviética. A vida de Lemme e a vida do 
país, como também a vida do povo brasileiro, possuem destinos entrelaçados, formando um todo orgânico.

Como em muitos enredos teatrais, a narrativa posta em cena contém certa polarização entre ideias, as quais repercutem na conduta dos personagens. Usualmente, a finalização do drama consiste na vitória de uma tese, a preferida pelo autor, sobre outra, considerada danosa, imprópria, representativa de posicionamentos equivocados assumidos pelos coadjuvantes da trama encenada. As memórias de Paschoal Lemme veiculam algo semelhante, pois o narrador elabora a oposição entre duas noções, "fatores educacionais" e "fatores econômicos", considerando que somente os últimos são capazes de alcançar progressos verdadeiros e duradouros, determinando, inclusive, o sucesso dos primeiros.

Conforme exposto no terceiro capítulo deste trabalho, essa polarização decorre da forma como Lemme interpreta a filosofia política marxista, a qual, segundo ele, qualifica como inviável a renovação educacional antes que se efetivem profundas mudanças na vida econômica do país. Ao defenderem posição oposta, privilegiando reformas no ensino sem pleitear o fim do modelo capitalista, os escolanovista liberais estariam manifestando adesão à primeira noção em detrimento da segunda, não percebendo a relevância primordial dos "fatores econômicos" sobre os "fatores educacionais".

Perelman e Olbrechts-Tyteca (2005, p. 500) analisam essa forma discursiva que promove inicialmente a polarização entre noções, para em seguida hierarquizá-las em consonância com a preferência do orador. Trata-se da "dissociação de noções", a qual resulta em "pares filosóficos", como se encontra, por exemplo, em discursos que constroem a oposição entre corpo e alma, sujeito e objeto etc., termos dispostos em pares antitéticos cuja explanação acaba por revelar a tese de quem os articula, quando um dos termos assume posição privilegiada sobre o outro. Assim, qualquer que seja a esfera de atuação em pauta, a audiência conclui que o primeiro termo exprime equívoco, erro, sinalizando uma opção inválida, ineficaz.

Além de expor os fatos de maneira ordenada para que a audiência encontre neles um sentido de continuidade e unidade, o recurso argumentativo que confere à narrativa autobiográfica uma forma teatral deve possuir outra característica importante. O drama encenado pelo orador torna-se sensivelmente mais persuasivo quando são empregadas estratégias discursivas capazes de mobilizar emoções, de modo a criar certa empatia 
com a audiência e, assim, promover a aceitação da trama encenada, cuja meta consiste em transferir as qualidades da pessoa às teses por ela defendidas.

Uma das paixões examinadas por Aristóteles na Retórica (II, 1383a15) é a confiança, definida como o "oposto do medo"; o que "inspira a confiança é o contrário daquilo que gera o medo". Confiar significa acreditar que "as coisas que podem nos proporcionar segurança estão próximas", ao passo que as "temíveis estão ausentes ou distantes". Quando Paschoal Lemme conta que ainda criança descobriu sua vocação de educador, e que diante de tal certeza enfrentou dificuldades de toda ordem para seguir suas inclinações, desperta na audiência o sentimento de confiança, pois um homem com tal disposição não provoca temor; suas teses proporcionam segurança, uma vez que são poucos os que lutam com tamanha firmeza pelas ideias em que acreditam.

A narrativa de suas atuações no cenário da vida pública contribui para reforçar a confiança em sua pessoa e, consequente, em suas concepções políticas e educacionais. Entram nesse rol todas as narrativas de Lemme acerca de sua participação na vida pública, desde quando, ainda recém-formado, participou ao lado dos escolanovistas na reforma do ensino no Distrito Federal, tarefa que assumiu com afinco, visando contribuir para o bem do país. Contribui para o mesmo objetivo a afirmação de que os líderes do movimento de renovação educacional nutriam por ele sentimentos de amizade, colocando altas funções sob a sua responsabilidade.

O espírito missionário demonstrado pelo orador durante a sua vida profissional e a confiança nele depositada por pessoas tão respeitadas quanto Fernando de Azevedo e Anísio Teixeira depõe a seu favor perante a audiência, afastando qualquer temor pelas ideias por ele defendidas. O sentimento de confiança da audiência torna-se ainda mais reforçado pela imagem de que Lemme é um homem disposto a oferecer o seu bem-estar como sacrifício por uma causa comum, a transformação do país.

Há que se considerar a forte carga negativa trazida historicamente pelo marxismo, o que poderia despertar rejeição em muitos leitores. Lemme cuida de desfazer esse temor, afirmando que, desde seus primeiros contatos com tal filosofia política, na década de 1930, nunca estabeleceu vínculo formal com o Partido Comunista, o qual, já naquela época, era visto por muitos como poderosa ameaça. O autor narra que manteve proximidade com aquela agremiação somente após 1945, no curto período que os comunistas desfrutaram de legalidade. Não há o que temer, portanto, da associação do orador com uma entidade de caráter "secreto e misterioso", como ele mesmo diz, pois tal forma de atuação não é condizente com os princípios 
democráticos que ele adota - a "discussão livre" e a "liberdade de pensamento e ação" (LEMME, 1988b, p. 214).

Em suma, de maneira geral, a narrativa autobiográfica de Lemme transmite à audiência o sentimento positivo de "tranquilidade", paixão definida por Aristóteles na Retórica (II 1380a5) como contrária à "cólera"; a tranquilidade produz o "apaziguamento" da raiva, remetendo à sensação de calma, serenidade, inexistência de conflitos. Por tudo o que realizou como profissional, na condição de comunista que sobreviveu ao lado de pessoas com ideais políticos diferentes dos seus, o orador transmite ao leitor a imagem de homem isento de paixões negativas, uma pessoa cujas ideias não ameaçam e não visam despertar a ira; pelo contrário, almejam a paz e a tranquilidade na ordem social, o que se pode conquistar por meio de ações serenas, mesmo em situações adversas.

\section{A retórica de uma geração}

O discurso de Paschoal Lemme, no que se inclui a forma de argumentação que nele se pode identificar, integra um modo de expressão típico de homens que ilustraram vários momentos da vida brasileira, em especial nas primeiras décadas do século $\mathrm{XX}$. Segundo Pécaut (1990, p. 6), tais homens eram oriundos das elites, portadores de diplomas de cursos superiores, fato que os diferenciava da massa populacional. Os intelectuais, como se convencionou chamá-los, eram vistos como os únicos capazes de conduzir a "formação da sociedade", colocando-se a serviço do conhecimento, em sintonia com a "realidade nacional". O intelectual era aquele que se posicionava "à altura da construção da nação", portador da "identidade nacional”, verdadeiro "detentor do saber relativo às leis da evolução histórica".

Gomes (1996, p. 38) os qualifica como produtores de "bens simbólicos", imersos no campo político, membros de um círculo restrito de "especialistas" que atuavam diretamente no "processo de criação e transmissão cultural”. Em razão de suas habilidades para interpretar os acontecimentos sociais mais relevantes e produzir novas visões do mundo, atraíam a atenção de todos os que gravitavam em torno do poder político. Apesar de suas diferenças de idade, ideias e objetivos, os intelectuais do começo do século XX exibiam traços de pensamento e atuação semelhantes, o que permite classificá-los como pertencentes a uma geração.

Bastos (2003, p. 161) esclarece que os membros de uma geração possuem uma "físionomia comum", distinta de outras gerações. Cada geração exprime valores 
associados a uma temporalidade, à memória compartilhada concernente a certo processo coletivo, determinada por uma história peculiar. A geração une a história e a memória, sendo esta entendida como o "testemunho" de um conjunto de pessoas em certo tempo (GOMES, 1996, p. 40). Toda geração visa compreender a temporalidade em que se situa, para agir perante a sociedade com a finalidade de melhorar o futuro; o papel de uma geração é transformar a coletividade, firmando o caráter único que faz dela um todo homogêneo, apesar das diferenças entre os seus componentes (BASTOS, 2003, p. 160).

Para compreender uma geração, é preciso dar um "tratamento social ao tempo", considerando um "tempo exterior" e um "tempo interior" (GOMES, 1996, p. 40-42). O primeiro abrange fatos importantes ocorridos em determinada época histórica de uma região, país ou grupo; o segundo diz respeito ao modo como tais fatos foram experimentados pela coletividade, permitindo aflorar sentimentos de unidade e pertencimento. Os agrupamentos geracionais possuem uma "dimensão organizacional" composta por "intercâmbios sociais" que ocorrem durante algum tempo, de várias formas e em vários "lugares de sociabilidade" - como escolas, revistas e associações onde se realiza a tarefa de produzir e fazer circular as ideias. As gerações possuem também uma "dimensão simbólica" que se oculta no emaranhado de relações sociais constituídas por "vínculos de afetividade e hostilidade", os quais, por sua vez, contribuem para construir certa sensibilidade e visão do real, dando vida a "pequenos mundos intelectuais".

O conceito de "campo intelectual" advindo de Bourdieu é utilizado por Gomes (1996, p. 42-43) para examinar as dimensões organizacionais e simbólicas de uma geração. Um campo intelectual é um sistema de relações "dinâmico e marcado por lutas" que delimita a posição e a especialização de quem produz bens simbólicos, os quais, no processo de legitimação do poder, assumem importância singular. O estudo de determinado campo revela o lugar em que se movimentam os intelectuais, assim como as posições por eles assumidas; as "relações de aliança, as disputas, filiações e rupturas" de um grupo remetem às tradições de pensamento de determinada geração, as quais transportam identidades comuns. Conhecendo o "lugar e o espaço afetivo de sociabilidade" de uma geração, pode-se identificar o caráter que a memória comum de seus intelectuais busca apresentar (idem, p. 43-44).

Bastos (2003, p. 161) acrescenta que uma geração é composta pela distinção entre indivíduos "seletos" e "vulgares", cabendo aos primeiros dirigir os segundos, 
realizando um empreendimento considerado fundamental para a consolidação da sociedade a que pertencem. Os seletos, que são instituídos ou instituem a si mesmos como melhores, semeiam exemplos a serem seguidos pelos demais, tendo em vista o aprimoramento do povo; detentores de uma cultura invulgar e de um conhecimento ilustrado, concebem as suas próprias vidas como um ofício, uma "missão" que põe sobre eles a responsabilidade pela transformação da realidade vigente, tendo por objetivo alcançar um futuro próspero para todos.

Paschoal Lemme iniciou sua trajetória no magistério na década de 1920, época geralmente caracterizada como nascedouro da busca pela "gênese do Brasil Moderno", expressão que qualifica aquele momento como palco da introdução de costumes, métodos, ideias e diagnósticos que passaram a orientar uma geração (LAHUERTA, 1997, p. 93). Em meio à crise da república oligárquica e a consequente desilusão com o regime instaurado em 1889, fatores que dificultavam a construção de um novo país, os anos de 1920 deram margem a várias transformações - sociais, políticas, econômicas e culturais - reconhecidamente relevantes para o país. Cidades como Rio de Janeiro e São Paulo, marcadas pelo avanço da industrialização e da urbanização, enfrentaram fervorosa onda de mudança naquele tempo.

Os anos de 1920 conheceram o clamor dos intelectuais que questionavam as "concepções tradicionais" e as instituições fundadas pela república, tidas como alheias à realidade do país devido ao predomínio das oligarquias. A defesa da organização e modernização do Brasil caracterizou a geração que se constitui naquelas primeiras décadas do século (LAHUERTA, 1997, p. 93). Pécaut (1990, p. 21) analisa que os intelectuais de então eram frequentemente oriundos de famílias oligárquicas decadentes que perceberam a necessidade de abandonar o estilo de vida típico das camadas cultas, reconhecendo o valor da "profissionalização" e da participação política ativa; sofreram a influência da "inflação dos diplomas" provocada pelo aumento do número de faculdades livres, como também pela ampliação do mercado de bens culturais e pelo desenvolvimento econômico urbano.

Os traços típicos daquela geração sobreviveram até a década de 1940, sendo compartilhados por escritores, professores, médicos, engenheiros, advogados, dentre outros profissionais, membros da nova elite brasileira pautada pela tarefa de criar um "novo povo" e uma "nova cultura", a fim de assegurar a unidade do país (PÉCAUT, 1990, p. 15). Martins (1986, p. 12) considera que a cultura e a política eram os setores privilegiados por seu ímpeto modernizador, cujo intuito era questionar os padrões 
tradicionais vigentes. Embora articulado por pequeno número de intelectuais, o movimento modernista derivou desse posicionamento, representando a força inicial que indicava ao país o caminho da renovação. A Semana de Arte Moderna, realizada em 1922 na cidade de São Paulo, é ilustrativa das ações empreendidas por aqueles que buscavam uma nova configuração cultural, firmando assim as características daquela geração.

Pécaut (1990, p. 21) entende que, durante os primeiros anos da década de 1920, os intelectuais reivindicavam uma "ciência do social", sugerida por escritores da época como "artimanha" para que as suas vozes fossem ouvidas pelo governo brasileiro. Havia um anseio incessante por transformar o "artista em intelectual", o que era motivado pela crença no poder da ciência para gerar a "administração científica dos homens e da natureza" (LAHUERTA, 1997, p. 94). Martins (1986, p. 9) informa que o positivismo e o liberalismo eram os referenciais em voga nos círculos intelectuais, ainda que, em alguns momentos, fossem adotados de modo seletivo, e, em outros, de modo "extravagante". Diante das conturbações próprias de uma era de mudanças, os homens daquela geração enfrentaram uma crise de "identidade social" que os impulsionou a “problematizar” radicalmente seu papel na sociedade (LAHUERTA, 1997, p. 94).

Para Martins (1986, p. 13-14), essa crise deveu-se ao fato de aqueles intelectuais, mesmo compartilhando a esperança de renovar a nação, terem tomado consciência dos limites da transformação pretendida; o "atraso do país, a estreiteza dos espíritos" e os obstáculos da política geraram um "sentimento de isolamento e impotência". Em sua luta para modernizar o país, sentiam-se solitários, isolados em relação à sociedade, o que desenvolvia neles um sentimento de impotência para dar andamento às metas ambiciosas de sua missão. Segundo o mesmo autor, tal sentimento de incapacidade foi vivenciado de modo distinto por diversos pensadores daquela época, mas não atingiu aqueles que optaram pelo marxismo para dirimir suas dúvidas e incertezas.

Esse parece ter sido o caso de Paschoal Lemme, como se pode apreender da análise de sua narrativa autobiográfica. Suas memórias indicam que ele também vivenciou o que Martins (1986, p. 14) denomina "ambivalência", sentimento comum àqueles que assumiam posicionamento otimista perante os fins que almejavam, mas eram acometidos pelo pessimismo quanto aos meios para alcançá-los. É certo, também, que, juntamente com os demais integrantes daquela geração, Lemme empenhou-se com 
afinco na busca por definir sua "identidade social", assumindo o que o mesmo autor classifica como "caráter missionário".

Segundo Lahuerta (1997, p. 94-95), a ideia de missão já estava presente nos meios intelectuais desde o início da República, mas foi no decorrer dos anos de 1920 que adquiriu novos significados e maior abrangência; o messianismo tornou-se a principal característica daquela geração. Martins (1986, p. 16) considera que a construção da imagem messiânica da intelectualidade incluía atribuir a certo grupo de indivíduos o status de "iluminados", verdadeiros "heróis modernizadores" capazes de cumprir a "missão" de transformar um país atrasado, doente e analfabeto, em uma nação moderna, sadia e alfabetizada. A elaboração dessa autoimagem permitiu justificar as ações daqueles homens, cujas ideias foram então posicionadas como condutoras das aspirações do povo brasileiro.

A análise das memórias de Paschoal Lemme revela o uso dessa mesma estratégia discursiva - a transferência das qualidades pessoais do orador às ideias por ele defendidas. O emprego desse recurso pelos homens daquela geração - incluindo Lemme nesse rol - não tinha o intuito de levá-los a ocupar o espaço de alguma classe social, nem de autorizá-los a falar "em nome da nação", como bem assinala Martins (1986, p. 16); o que os movia era a intenção de conquistar o reconhecimento de sua condição de intelectuais e ver legitimada a sua "liderança moral". Em busca de sua "identidade social”, o intelectual daquela geração posicionava a si mesmo como "herói modernizador", dotado da missão de reconstruir a nação brasileira, colocando no centro de suas preocupações a tarefa da "organização nacional".

Não se buscava uma "revolução", mas "organizar um país real" a partir de preceitos científicos; resgatar o país do atraso histórico responsável pelo "desencanto" com a política. Muitos daqueles homens recorreram ao "princípio abstrato de organização", sendo conduzidos a uma "visão tecnocrática da mudança social" em que se incluía a proposta de reformar a sociedade por meio da reforma da educação e do ensino público, o que resultaria na "criação dos homens e técnicos" que o país necessitava (MARTINS, 1986, p. 16).

Essa caracterização também permite situar Lemme na esfera da referida geração, cujo plano de ação consistia em denunciar as estruturas "rígidas e atrasadas" do Brasil. Com seu discurso autobiográfico, Lemme posiciona-se ao lado dos intelectuais que se viam como pertencentes à fatia "civilizada" e "enraizada" da sociedade, convictos da relevância de sua contribuição à mudança das estruturas sociais do país. Seu problema 
comum era encontrar a maneira certa para desempenhar sua missão modernizadora. Anísio Teixeira ofereceu uma resposta a essa indagação ao afirmar que o poder das ideias era insuficiente para superar a vigente "estreiteza dos espíritos"; para modernizar o Brasil fazia-se necessário agir, não persuadir.

As reformas do ensino promovidas nos anos de 1920 e 1930 por educadores como Anísio Teixeira e Fernando de Azevedo - com o apoio de Paschoal Lemme tinham a meta de educar o povo por meio da instrução pública; um novo "campo cultural" seria instituído com a criação da universidade, que viria fomentar a "reprodução/modernização" das elites e "orientar a nação" com base em pesquisas, além de disseminar a cultura modernizadora por todo o país (MARTINS, 1986, p. 16-17). Várias instituições inovadoras foram criadas para instituir o "espírito de renovação e pesquisa", em busca de eliminar o atraso histórico do Brasil. Exemplo desse empenho foi a Associação Brasileira de Educação, à qual Lemme pertenceu; fundada em 1924, a ABE abriu caminho para aquela geração de intelectuais ampliar o reconhecimento de sua missão perante a sociedade.

Ao instalar o governo provisório em 1930, Getúlio Vargas logo criou o Ministério da Educação e Saúde, estabelecendo rígida tutela sobre todos os níveis de ensino. A margem de influência dos intelectuais foi então sensivelmente reduzida, o que tornou a sua missão modernizadora na esfera educacional dependente de alianças com o Estado, instituído como representante do interesse geral da nação. Os intelectuais dividiram-se nas várias vertentes políticas - liberais, católicos, fascistas e comunistas -, o que deu início à sua dispersão, os distanciando ainda mais de função missionária (MARTINS, 1986, p. 18-19).

Durante o Estado Novo, entre 1937 e 1945, a situação foi agravada pela total centralização das iniciativas de reforma do sistema educacional, o que praticamente decretou o fim da busca pela identidade e o encerramento da fase de prestígio da geração de intelectuais formada na década de 1920 (MARTINS, 1986, p. 22). Suas narrativas, no entanto, sobreviveram ao tempo, servindo de contribuição para as gerações seguintes: a apresentação bem articulada de seus feitos e ideias, os elevando à condição de mitos de uma época; o discurso em que se apresentam como dotados de capacidades ímpares, protagonistas do drama vivido pelo país no início do século XX, os posicionando como faróis acessos em direção ao futuro; seu ideal missionário, construído na forma de uma cena teatral, os colocando como exemplos de conduta e de fidelidade a um ideário. 
Antes de escrever as suas memórias, Paschoal Lemme não figurava no panteão dos heróis da geração que tanto influenciou o Brasil entre os anos de 1920 e 1940. Ao publicar sua autobiografia, seu nome foi inscrito definitivamente naquele conjunto de intelectuais, podendo, como eles, legar à posteridade as suas contribuições. Esse é um dos objetivos das narrativas memorialísticas: servir de norte para os que vivem o presente, em especial quando o presente não oferece perspectivas claras para a ação.

Eis aqui uma indicação para o exame da relação de Paschoal Lemme com sua audiência, os leitores de suas memórias, os educadores da década de 1980. 


\section{CONSIDERAÇÕES FINAIS}

O trabalho ora concluído teve por objetivo defender que as narrativas memorialísticas podem ser examinadas por meio da perspectiva teórica e metodológica denominada análise retórica, tal qual se encontra em desenvolvimento nas produções do Grupo de Pesquisa Retórica e Argumentação na Pedagogia, cujas bases estão nas contribuições de Chaïm Perelman e outros autores vinculados ao movimento contemporâneo de revisão da filosofia aristotélica. Para isso, em continuidade a pesquisas anteriormente realizadas, procedeu-se a uma nova leitura das memórias do educador Paschoal Lemme.

Esta dissertação procurou mostrar que uma autobiografia, a exemplo de outros textos, pode ser lida como um discurso propositivo, destinado a reforçar ou modificar as concepções dos leitores. Com esse intuito, são investigados os qualificativos do autor do texto no contexto de sua produção, o que, no âmbito da análise retórica, denomina-se ethos do orador; o discurso (logos) em que se apresentam as teses com as quais o orador busca influenciar as disposições intelectuais e emocionais (pathos) de determinada audiência; e, por fim, as características dessa audiência, levando em conta as condições gerais ou específicas do momento em que o discurso é pronunciado.

Após a discussão teórica feita no primeiro capítulo, cuja intenção foi propor a análise retórica como alternativa válida para o exame de discursos memorialísticos, teve início a investigação das fontes primárias, as memórias de Lemme, publicadas nos anos de 1980, nas quais o autor descreve fatos de sua trajetória pessoal e profissional, além de transcrever textos de sua autoria elaborados durante o período áureo do escolanovismo no Brasil.

Assim, o capítulo segundo apresentou o ethos do orador, procurando evidenciar que a narrativa autobiográfica em exame cria a imagem de Paschoal Lemme como um missionário, homem vocacionado, predestinado desde a infância para lidar com assuntos da educação, capaz de enfrentar todos os tipos de obstáculos para alcançar sua meta em prol do país e de seu povo, particularmente aqueles a quem historicamente foram negados os bens materiais e culturais da sociedade.

O terceiro capítulo discorreu sobre o logos do orador, focalizando as teses políticas e educacionais defendidas por Lemme, de maneira a mostrar que seu fundamento residia em uma interpretação da filosofia marxista que considera secundários os problemas escolares, uma vez que a sua solução depende de 
transformações radicais nas bases econômicas da sociedade; a sociedade sem classes, cujo modelo proposto pelo autor é a União Soviética, é condição prévia para qualquer iniciativa de reforma do ensino que se pretenda verdadeiramente efetiva.

No quarto capítulo foi feita a análise retórica do discurso do orador, tal qual exposto nas duas seções precedentes do trabalho, tomando por base o referencial apresentado no capítulo inicial. Procurou-se mostrar que a narrativa memorialística de Lemme faz uso da estratégia discursiva que consiste em transferir as qualidades da pessoa às ideias por ela defendidas e aos atos por ela praticados. Assim, a imagem construída por Lemme para descrever a si próprio - o missionário que se sacrifica por uma causa em prol da coletividade - avaliza o marxismo por ele abraçado, validando a tese de que, antes de reformar a educação, é preciso transformar a ordem social.

Nesse mesmo capítulo, foi analisado que a narrativa de Lemme assemelha-se a uma peça teatral em que o protagonista luta contra todas as adversidades, assumindo o papel de herói no interior de um drama, figurado, no caso em exame, como o drama de um país que requer solução. Esta interpretação é favorecida pela ordenação do discurso de Lemme, que constrói perante a audiência a imagem do lutador incompreendido em sua época, porém vitorioso nos dias atuais, quando suas ideias são finalmente reconhecidas pela comunidade acadêmica dos educadores. Como foi então exposto, tais ideias são dispostas na forma de um par filosófico em que os fatores econômicos são hierarquicamente superiores aos fatores educacionais.

O capítulo discorreu também sobre o fato de que todo discurso pretensamente persuasivo busca estabelecer algum vínculo emocional com a audiência. A narrativa de Lemme, entendida como um discurso dessa natureza, desperta no leitor as paixões que Aristóteles, na Retórica, denomina confiança e tranquilidade. Toda a sua trajetória de vida é mostrada como voltada para o bem comum, sendo as suas ideias, portanto, incapazes de despertar temor e aversão. Trata-se de um homem em quem se pode confiar, pois, segundo ele mesmo, seus ideais visam unicamente ao bem coletivo, à plena realização da democracia e da liberdade.

Finalizando a análise, o capítulo procurou mostrar que as características do discurso de Lemme, segundo o que foi possível investigar neste trabalho, são comuns à geração dos intelectuais que atuou no Brasil entre as décadas de 1920 e 1940. Considerou-se, então, que ao elaborar as suas memórias, assumindo tais características, Lemme posicionou-se ao lado daqueles homens cujas teses constituíram norteamentos para a transformação do país. Lemme galga uma posição de autoridade moral para 
discursar perante os educadores da década de 1980, quando a sua narrativa memorialística foi publicada.

Esta reflexão remete à necessidade de examinar a audiência de Paschoal Lemme, o que viria completar a análise retórica de seu discurso, segundo os parâmetros metodológicos adotados neste trabalho. Conforme foi assinalado na seção introdutória desta dissertação, para alcançar essa meta seria preciso realizar uma investigação específica, dedicada a compreender o contexto vivido pelos educadores dos anos de 1980 - o que não seria viável no âmbito desta pesquisa.

É possível, no entanto, apresentar algumas reflexões sobre o tema, tendo em vista as teses do autor e as estratégias argumentativas identificadas em sua narrativa pela análise retórica. É plausível supor que a publicação da autobiografia de Lemme tenha buscado preencher uma lacuna nas concepções dos educadores da época. Naquele momento, havia sinais mais ou menos claros de que o Brasil caminhava para a redemocratização, após um longo período de ditadura militar. Em contextos de transição como aquele, é comum que se instalem divergências sobre os posicionamentos a adotar no que tange à relação entre educação e sociedade.

No início da década de 1980, várias entidades começaram a se organizar com o intuito de encontrar alternativas para enfrentar aquele conturbado contexto. Essa iniciativa consolidou-se em vários eventos de educadores, como foi a II Conferência Brasileira de Educação realizada em 1982, ocasião em que, conforme foi mencionado no segundo capítulo deste trabalho, Paschoal Lemme foi homenageado e fez um contundente pronunciamento defendendo a tese de que os problemas educacionais do país eram de natureza política e social, muito além da esfera estritamente pedagógica.

As bandeiras do movimento de renovação educacional que havia contagiado o país a partir da década de 1920 ainda estavam na memória dos educadores. Quando Dermeval Saviani (2004, p. 186) participou da I Conferência Brasileira de Educação, ocorrida em 1980, julgou possível supor que "o ideário da Escola Nova havia se tornado hegemônico e, nessa condição, havia ganhado a cabeça dos professores". Motivado por essa percepção, Saviani optou por apresentar a imagem da "curvatura da vara", mais tarde celebrizada em seu livro Escola e democracia: "propus-me - diz o autor - a inverter a posição dominante que considerava a Escola Nova portadora de todas as virtudes e nenhum vício em contraposição à escola tradicional, considerada portadora de todos os vícios e de nenhuma virtude". 
O momento, portanto, era propício ao debate sobre concepções políticas para o enfrentamento dos novos tempos que se anunciavam. Uma alternativa ao ideário da Escola Nova era o marxismo, em suas variadas vertentes de interpretação. A narrativa autobiográfica de Paschoal Lemme pode ter representado um importante elemento de persuasão dos educadores da década de 1980, ao promover a desqualificação do escolanovismo em benefício de outra visão acerca dos problemas educacionais do Brasil. 


\section{REFERÊNCIAS BIBLIOGRÁFICAS}

ARISTÓTELES. Retórica. Tradução Edson Bini. São Paulo: Edipro, 2011.

ALBERTI, Verena. Ouvir e contar textos em história oral. Rio de Janeiro: FGV, 2004. AMADO, Janaína; FERREIRA, Moraes Marieta. Usos e abusos da história oral. Rio de Janeiro: FGV, 2006.

BASTOS, Elide Rugai. A revista Cultura Política e a influência de Ortega y Gasset. In: BASTOS, Elide Rugai; RIDENTI, Marcelo; ROLLAND, Denis (Orgs.). Intelectuais: sociedade e política. São Paulo: Cortez, 2003.

BENJAMIN, Walter. Obras escolhidas - Magia e técnica. Arte e política. São Paulo, Brasiliense, 1994.

BERTI, Enrico. As razões de Aristóteles. Tradução Davi Dion Macedo. São Paulo: Loyola, 1998.

BILLIG, Michael. Argumentando e pensando: uma abordagem retórica à psicologia social. Tradução Vera Lúcia Mello Joscelyne. Petrópolis: Vozes, 2008.

BOURDIEU, Pierre. A ilusão biográfica. In: AMADO, Janaína; FERREIRA, Moraes Marieta (Orgs.). Usos e abusos da história oral. 8. edição. Rio de Janeiro: FGV, 2006.

BRANDÃO, Zaia. A intelligentsia educacional: um percurso com Paschoal Lemme por entre as histórias e memórias da Escola Nova no Brasil. Bragança Paulista: EDUSF, 1999.

BRANDÃO, Zaia. Paschoal Lemme. In: FÁVERO, Maria de Lourdes Albuquerque; BRITTO, Jader de Medeiros (Orgs.). Dicionário de educadores no Brasil: da Colônia aos dias atuais. 2. ed. Rio de Janeiro: UFRJ \& MEC/INEP/COMPED, 2002a.

BRANDÃO, Zaia. Paschoal Lemme, marxista e pioneiro da educação nova. In: FREITAS, Marcos Cezar (Org.). Memória intelectual da educação brasileira. 2. ed. Bragança Paulista: EDUSF, 2002 b.

BRANDÃO, Zaia. O sentido de uma trajetória: Paschoal Lemme, do Manifesto dos Pioneiros (1932) ao Manifesto dos Inspetores (1934). In: MAGALDI, Ana Maria; GONDRA, José (Org.). A reorganização do campo educacional no Brasil. Rio de Janeiro: 7 Letras/FAPERJ, 2003.

CARVALHO, Marta Maria Chagas. Molde nacional e fôrma cívica: higiene, moral e trabalho no projeto da Associação Brasileira de Educação (1924-1931). Bragança Paulista: EDUSF, 1998.

CHAUÍ, Marilena. Convite à filosofia. São Paulo: Ática, 1995. 
CHESNEAUX, Jean. Devemos fazer tabula rasa do passado? Sobre a História e os historiadores. Tradução Marcos da Silva. São Paulo: Ática, 1995.

CUNHA, Célio. Educação e autoritarismo no Estado Novo. 2. edição. São Paulo: Cortez/ Autores Associados, 1989.

CUNHA, Marcus Vinicius. Recontextualização e retórica na análise de discursos pedagógicos. In: SOUZA, Rosa Fátima; VALDEMARIN, Vera Teresa (Orgs.). A cultura escolar em debate: questões conceituais, metodológicas e desafios para a pesquisa. Campinas: Autores Associados, 2005.

CUNHA, Marcus Vinicius. O conhecimento e a formação humana no pensamento de Aristóteles. In: PAGNI, Pedro Angelo; SILVA, Divino José (Orgs.). Introdução à Filosofia da Educação: temas contemporâneos e história. São Paulo: Avercamp, 2007.

CUNHA, Marcus Vinicius. História da Educação e Retórica: ethos e pathos como meios de prova. In: SILVA, Marilda; VALDEMARIN, Vera Teresa (Orgs.). Pesquisa em educação: métodos e modos de fazer. São Paulo: Cultura Acadêmica, 2010.

DELGADO, Lucilia de Almeida Neves. História oral: memória, tempo, identidades. 2. edição. Belo Horizonte: Autêntica, 2010.

FERREIRA, Marieta Morais. História do tempo presente: desafios. Cultura Vozes, Petrópolis, v. 94, n. 3, p. 111-124, 2000.

FRANÇOIS, Etienne. A fecundidade da história oral. Tradução Luis Alberto Monjardim, Maria Lúcia Leão Velloso de Magalhães, Glória Rodriguez, Maria Carlota C. Gomes. In: AMADO, Janaína; FERREIRA, Moraes Marieta (Orgs.). Usos e abusos da história oral. Rio de Janeiro: FGV, 2006.

GINZBURG, Carlo. Relações de força: histórica, retórica, prova. Tradução Jônatas Batista Neto. São Paulo: Companhia das Letras, 2002.

GOMES, Ângela de Castro. História e historiadores: a política cultural do Estado Novo. Rio de Janeiro: FGV, 1996.

GROSSI, Yonne; FERREIRA, Amauri. Razão narrativa: significado e memória. Revista História Oral, ABHO, São Paulo, v. 4, p. 25-38, jun. 2001.

GUARINELLO, Norberto Luiz. Memória coletiva e história científica. Revista Brasileira de História, ANPUH, São Paulo, v. 14, n. 28, p. 180-193, 1994.

HORTA, José Silvério Baía. O hino, o sermão e a ordem do dia: regime autoritário e a educação no Brasil (1930-1945). Rio de Janeiro: UFRJ, 1994.

HOUAISS, Antônio. Prefácio. In: LEMME, Paschoal. Memórias: infância, adolescência, mocidade. São Paulo: Cortez, 1988. 
KASTELIC, Eloá Soares Dutra. O percurso de Paschoal Lemme: defesa da escola pública, gratuita e estatal. Campinas: Autores Associados, 2014.

KHOURY, Yara Aun. Muitas histórias, outras memórias: cultura e o sujeito na história. In: FENELON, Déa. Muitas memórias, outras histórias. São Paulo: Olho D’Água, 2000 .

LAHUERTA, Milton. Os intelectuais e os anos 20: moderno, modernista, modernização. In: LORENZO, Helena Carvalho; COSTA, Wilma Peres (Orgs.). A década de 1920 e as origens do Brasil moderno. São Paulo: UNESP, 1997.

LE GOFF, Jacques. História e memória. Tradução Irene Ferreira, Bernardo Leitão, Suzana Ferreira Borges. 5. edição. Campinas: UNICAMP, 2003.

LEMME, Paschoal. Memórias: infância, adolescência, mocidade. São Paulo: Cortez, 1988a.

LEMME, Paschoal. Memórias: vida de família, formação profissional, opção política. São Paulo: Cortez, 1988b.

LEMME, Paschoal. Memórias: reflexões e estudos sobre problemas da educação e ensino. Perfis: Anísio Teixeira, Fernando de Azevedo, Heloísa Alberto Torres, Humberto Mauro, Sousa Silveira. São Paulo: Cortez, 1988c.

LEMME, Paschoal. Memórias: estudos de educação e destaques da correspondência. 2. edição. Brasília: INEP, 2004a.

LEMME, Paschoal. Memórias: estudos de educação, participação em conferências e congressos; documentos. 2. edição. Brasília: INEP, 2004b.

LEVI, Giovanni. Usos da biografia. In: AMADO, Janaína; FERREIRA, Moraes Marieta (Orgs.). Usos e abusos da história oral. Rio de Janeiro: FGV, 2006.

LORIGA, Sabina. A biografia como problema. In: REVEL, Jacques (Org.). Jogos de escalas: a experiência da microanálise. Rio de Janeiro: FGV, 1998.

MAIA, Andréa Casanova; ARRUDA, Rogério. Nos trilhos do tempo: memória da ferrovia em Pedro Leopoldo. Belo Horizonte: Maza, 2003.

MARTINS, Luciano. A gênese de uma intelligentsia: os intelectuais e a política no Brasil, 1920-1945. Tradução Yamara Villalobos. Revista Brasileira de Ciências Sociais, Paris, v. 2, n. 4, p. 1-25, jun. 1986.

MATE, Cecília Hanna. Tempos modernos na escola: os anos 30 e a racionalização da educação brasileira. Bauru: EDUSC, 2002. 
MEYER, Michel. Aristóteles ou a retórica das paixões. In: ARISTÓTELES. Retórica das paixões. 2. edição. Tradução Isis Borges B. da Fonseca. São Paulo: Martins Fontes, 2003.

NAGLE, Jorge. Educação e sociedade na Primeira República. 2. edição. Rio de Janeiro: DP\&A, 2001.

NUNES, Clarice. As contribuições da sociologia da educação para a pesquisa histórica. In: PAIXÃO, Lea Pinheiro; ZAGO, Nadir. (Orgs.). Sociologia da educação: pesquisa e realidade brasileira. 2. edição. Petrópolis: 2011.

PAGNI, Pedro Angelo. Anísio Teixeira: experiência reflexiva e projeto democrático - a atualidade de uma filosofia da educação. Petrópolis: Vozes, 2008.

PAIVA, Vanilda. Prefácio. In: LEMME, Paschoal. Memórias: estudos de educação e destaques da correspondência. 2. edição. Brasília: INEP, 2004.

PÉCAUT, Daniel. Os intelectuais e a política no Brasil: entre o povo e a nação. Tradução Maria Júlia Goldwasser. São Paulo: Ática, 1990.

PERELMAN, Chaïm; OLBRECHTS-TYTECA, Lucie. Tratado da argumentação: a nova retórica. Tradução Maria Ermantina de Almeida Prado Galvão. 2. edição. São Paulo: Martins Fontes, 2005.

PINTO, Pimentel Júlio. Uma memória do mundo: ficção, memória e história em Jorge Luís Borges. São Paulo: Estação Liberdade, 1998.

POULET, Georges. O espaço proustiano. Tradução Ana Luiza Borralho Martins Costa. Rio de Janeiro: Imago, 1992.

REALE Giovanni. História da filosofia antiga: V. Léxico, índices, bibliografia. 2. edição. Tradução Henrique C. de Lima Vaz e Marcelo Perine. São Paulo: Loyola, 2001. REALE, Giovanni. História da filosofia antiga. II. Platão e Aristóteles. 2. edição. Tradução Henrique C. de Lima Vaz e Marcelo Perine. São Paulo: Loyola, 2002.

RICOUER, Paul. Tempo e narrativa. Tomo III. Tradução Roberto Leal Ferreira. Campinas: Papirus, 1997.

SAVIANI, Dermeval. Setenta anos do Manifesto e 20 anos de Escola e democracia: balanço de uma polêmica. In: XAVIER, Maria do Carmo (Org.). Manifesto dos pioneiros da educação: um legado educacional em debate. Rio de Janeiro: FGV, 2004.

SIRCILLI, Fabíola. A argumentação de Arthur Ramos a favor da Psicanálise na Educação: análise retórica de um livro-argumento. 2006. 54 f. Dissertação (Mestrado em Psicologia) - Faculdade de Filosofia, Ciências e Letras de Ribeirão Preto, Universidade de São Paulo, Ribeirão Preto, 2006. 
SOUSA, Cynthia Pereira de. A evocação da entrada na escola: Relatos autobiográficos de professores e professoras. In: BUENO, Belmira Oliveira; CATANI, Denice Barbara; SOUSA, Cynthia Pereira de (Orgs.). A vida e o ofício dos professores: formação contínua, autobiografia e pesquisa em colaboração. São Paulo: Escrituras, 1998.

SOUZA, Aline Vieira de. Análise Retórica do Discurso Político-Educacional de Cecília Meireles. 2014. 103 f. Dissertação (Mestrado em Educação) - Faculdade de Filosofia, Ciências e Letras de Ribeirão Preto, Universidade de São Paulo, Ribeirão Preto, 2014.

THOMSON, Alistair; FRISCH, Michael; HAMILTON; Paula. Os debates sobre memória e história: alguns aspectos internacionais. In: AMADO, Janaína; FERREIRA, Moraes Marieta (Orgs.). Usos e abusos da história oral. Rio de Janeiro: FGV, 2006.

TOULMIN, Stephen. Os usos do argumento. Tradução Reinaldo Guarany. São Paulo: Martins Fontes, 2001.

XAVIER, Libânia Nacif. O Manifesto dos pioneiros da educação nova como divisor de águas na história da educação brasileira. In: XAVIER, Maria do Carmo (Org.). Manifesto dos pioneiros da educação: um legado educacional em debate. Rio de Janeiro: FGV, 2004. 